\title{
Preparation of Anatase Titanium Dioxide Nanoparticle Powders Submitting Reactive Oxygen Species (ROS) under Dark Conditions
}

\section{Thi Minh Phuong Nguyen1, Perrine Lemaitre', Masaki Kato', Ken Hirota ${ }^{1}{ }^{*}$, Kazuhiko Tsukagoshi', Hirohisa Yamada ${ }^{2}$, Atsuki Terabe ${ }^{3}$, Hideto Mizutani ${ }^{3}$, Shingo Kanehira ${ }^{4}$}

${ }^{1}$ Applied Chemistry, Graduate School of Science and Engineering, Doshisha University, Kyoto, Japan

${ }^{2}$ Department of Chemical Engineering, National Institute of Technology, Nara College, Nara, Japan

${ }^{3}$ Sakai Chemical Industry Co., Ltd., Sakai, Japan

${ }^{4}$ Microwave Chemical Co., Ltd., Osaka, Japan

Email: *khirota@mail.doshisha.ac.jp

How to cite this paper: Nguyen, T.M.P., Lemaitre, P., Kato, M., Hirota, K., Tsukagoshi, K., Yamada, H., Terabe, A., Mizutani, H. and Kanehira, S. (2021) Preparation of Anatase Titanium Dioxide Nanoparticle Powders Submitting Reactive Oxygen Species (ROS) under Dark Conditions. Materials Sciences and Applications, 12, 89110.

https://doi.org/10.4236/msa.2021.122006

Received: December 20, 2020

Accepted: February 1, 2021

Published: February 4, 2021

Copyright ( 2021 by author(s) and Scientific Research Publishing Inc. This work is licensed under the Creative Commons Attribution International License (CC BY 4.0).

http://creativecommons.org/licenses/by/4.0/

\begin{abstract}
Recently, under the circumstances of pandemic of COVID-19 much attention has been paid to titanium dioxide $\mathrm{TiO}_{2}$ as bactericidal agent; however, conventional $\mathrm{TiO}_{2}$ requires ultraviolet radiation or visible light to exercise its photocatalytic properties and its induced antimicrobial activity. In order to expand its applications directed at wide civil life, antibacterial $\mathrm{TiO}_{2}$ being usable under dark conditions has been demanded. The present paper describes the powder characterization of newly developed potassium $\mathrm{K}$ and phosphorous $\mathrm{P}$ co-doped nanometer-size anatase $\mathrm{TiO}_{2}$ powders using X-ray diffraction (XRD), scanning and transmission electron microscopies (SEM \& TEM), BrunauerEmmett-Teller method (BET), fourier-transform infrared spectroscopy (FT-IR), $\mathrm{X}$-ray absorption fine structure (XAFS), electron spin resonance (ESR) and chemiluminescence (CL). It was found for the first time that thus prepared anatase $\mathrm{TiO}_{2}$ could submit much reactive oxygen species (ROS) even in the dark, which has close relation with bactericidal activity in light interception.
\end{abstract}

\section{Keywords}

Anatase, Microbial Activity under Dark Conditions, Potassium K,

Phosphorous $\mathrm{P}$

\section{Introduction}

Three crystal structures of titanium dioxide are mainly reported: low-temperature 
form tetragonal anatase $\left(a-\mathrm{TiO}_{2}\right)$, high-temperature stable tetragonal rutile $\left(r-\mathrm{TiO}_{2}\right)$ and middle temperature orthorhombic brookite $\left(b-\mathrm{TiO}_{2}\right)$ [1]. The first $a-\mathrm{TiO}_{2}$ and third $b$ - $\mathrm{TiO}_{2}$ transform easily into $r-\mathrm{TiO}_{2}$ at higher temperatures than 1188 $\mathrm{K}$ and $923 \mathrm{~K}$, respectively [2]; these temperatures depend on their particle and crystallite sizes, purity and synthetic process conditions [3]. Among them, $r-\mathrm{TiO}_{2}$ has been widely used in the industry that is textiles, electronics, wastewater treatment, and catalysis [4] [5] [6]. Recently, $\mathrm{TiO}_{2}$ nanoparticles ( $\mathrm{TiO}_{2} \mathrm{NPS}$ ), have been attracting much attention due to their functional and physicochemical properties, such as, a white pigment and a personal skin care product (due to its brightness and high refractive index with high safety margin), and bactericidal agents (photocatalytic properties and its induced antimicrobial activity under ultraviolet (UV) radiation or visible light) [7] [8] [9]. Up to now, many papers and reviews concerning about toxicity mechanism have been published from the viewpoints of reactive oxygen species (ROS) [10]-[17], that is hydroxyl radical $\cdot \mathrm{OH}$ and superoxide anion $\mathrm{O}_{2}^{-}$which are generated by hole-electron pairs in the valence and conduction bands of $\mathrm{TiO}_{2}$, respectively. Their bactericidal mechanism has been explained by introducing bio-cell wall damage and lipid peroxidation of membrane, and $\mathrm{TiO}_{2}$ NPS's adherence to intercellular organelles and biological macro molecules [17] [18] [19] [20] [21].

The authors have been studying metal oxide powders which can reveal strong antimicrobial activity in the shade for long time. Biocompatible zinc oxide $\mathrm{ZnO}$ also has been interested due to its microbial toxicity. However, its activity is a little lower than $\mathrm{TiO}_{2}$ NPS. Recently, $\mathrm{ZnO}$ powders have been prepared by hydrothermal treatment in zinc nitrate aqueous solution with a concentration of 3 $\mathrm{mol} \cdot \mathrm{L}^{-1}$ at $443 \mathrm{~K}$ for $2.52 \times 10^{4} \mathrm{~s}$, followed by re-oxidation heating at $873 \mathrm{~K}$ for $3.6 \times 10^{3} \mathrm{~s}$ in air. And then it has been cleared that thus obtained $\mathrm{ZnO}$ powders can reveal strong antibacterial activity even under dark conditions [22] [23] [24]. During investigation of antibacterial $\mathrm{ZnO}$, the authors found that 1) among commercially available $\mathrm{TiO}_{2}$ powders, some $a-\mathrm{TiO}_{2}$ could submit a small amount of ROS in the dark, however, $r-\mathrm{TiO}_{2}$ did not, and furthermore, 2) among $a-\mathrm{TiO}_{2}$, ROS were submitted from $a-\mathrm{TiO}_{2}$ which contained a trace amount of potassium $\mathrm{K}$ and phosphorus $\mathrm{P}$ as impurities.

The effects of potassium $\mathrm{K}$ doping on physicochemical properties of $\mathrm{TiO}_{2}$, such as their crystallinity, surface areas $S_{\mathrm{A}}$, solubility, photocatalytic activity, and band gap $E_{g}$, were studied by several researchers [25] [26] [27] [28]. Their results were summarized as follows; K-solubility was a very low around 0.2 at $\%$, therefore, $E_{\mathrm{g}}$ was not changed and photocatalytic activity was decreased under visible light conditions. Hao et al. [29] studied the antibacterial activity of $\mathrm{K}$-doped $\mathrm{TiO}_{2}$ powders, which were prepared using molten potassium nitrate $\mathrm{KNO}_{3}$ and metal $\mathrm{Ti}$ under various calcination temperatures. The obtained samples consisted of $a-\mathrm{TiO}_{2}$ as well as metal Ti. Doped (2.6 - 10.6 at $\% \mathrm{~K}) \mathrm{TiO}_{2}$ samples showed a photocatalytic activity under visible light conditions, despite having a small change in the band gap $(3.14 \mathrm{eV})$, contradicting a previous study [27]. They assumed that $\mathrm{K}^{+}$ 
ions decreased $E_{\mathrm{g}}$ of $a-\mathrm{TiO}_{2}$ and the doped samples killed bacteria under visible light conditions. Under dark conditions, the samples also showed some antibacterial activity.

$\mathrm{Yu}$ et al. [30] studied phosphorus-doped $\mathrm{TiO}_{2}$ powders and reported their microstructures; phosphate $\mathrm{P}$ doping inhibited the grain growth during calcination, significantly increasing $S_{\mathrm{A}}$, and decreased the pore size. About the values of $E_{\mathrm{g}}$, opposite results were reported, $E_{\mathrm{g}}$ became larger [30] and smaller [31] [32] than those of undoped one. This might be explained in terms of a different source of $\mathrm{P}$ and way of synthesis method. Shi et al. [32] investigated the bonding of $\mathrm{P}$ in the crystal structure and reported that $\mathrm{P}$ was only present as $\mathrm{P}^{5+}$, and only Ti-O-P bonds were detected. This substitution consequently led to a charge imbalance, which needs to be compensated. The compensation was proved through the decrease in oxygen vacancies. It is known that decreasing oxygen vacancies improved photocatalytic activity, because oxygen vacancies acted as recombination centres for electron-hole pairs [33] [34]. In addition, they also observed an increase in the photocatalytic activity with increasing the $\mathrm{P}$ content. Jin et al. [35] found that $P$ doping increased hydroxyl radical emission from the surface, which was also favourable in terms of photocatalytic activity.

$\mathrm{Up}$ to now, there is no report on the generation of ROS from $a-\mathrm{TiO}_{2} \mathrm{NPS}$ under dark conditions. Then, we started to investigate the relationship between the amount of ROS and the contents of K, P, and their combined doping, from the viewpoint of the microstructure and physicochemical properties. Finally, we found that anatase $\left(a-\mathrm{TiO}_{2}\right)$ powders which could submit a lot of ROS even in the dark; the amounts of ROS were much higher than our previous antibacterial $\mathrm{ZnO}$, in addition, this powder could be prepared with much simpler process. The present paper treats the physicochemical properties in relation with the microbial toxicity of thus prepared anatase $\left(a-\mathrm{TiO}_{2}\right)$ as a function of impurity contents and its doping method.

\section{Experimental Procedure}

\subsection{Preparation of Doped $\mathrm{TiO}_{2}$ Powders}

As shown in Figure 1, fine anatase $\mathrm{TiO}_{2}$ powder (W-4038, 99.92\% of purity, Sakai Chemical Industry Co., Ltd., Osaka, Japan) with a BET $S_{\mathrm{A}}$ of $55.1 \mathrm{~m}^{2} / \mathrm{g}$, i.e., particle size $P_{\mathrm{s}}$ of $0.0280 \mu \mathrm{m}$, which was calculated from the values of $S_{\mathrm{A}}$ and theoretical density $D_{\mathrm{x}}$ of $3.895 \mathrm{Mg} \cdot \mathrm{m}^{-3}$ (Powder Diffraction File PDF: \#21-1272), was used as the starting material. $0.1 \mathrm{~mol}$ of this powder and a certain amount of $\mathrm{KHCO}_{3}$ (99.7\%, Sigma Aldrich, Japanese agency Nacalai Tesque Chemicals, Kyoto, Japan) and $\left(\mathrm{NH}_{4}\right)_{2} \mathrm{HPO}_{4}(\geq 98 \%$, Sigma Aldrich) with various inner atomic ratios (0.01 - 10.0 at\%) of $\mathrm{K}$ and $\mathrm{P}$ for single or double additions (co-doping), as shown in Table 1, were mixed together in $1.5 \times 10^{-5} \mathrm{~m}^{3}(15 \mathrm{~mL})$ ethanol for 9.0 $\times 10^{2} \mathrm{~s}$ at room temperature. The mixtures were subsequently dried at $393 \mathrm{~K}$ for $4.32 \times 10^{4} \mathrm{~s}$ in air, and then heated at $973 \mathrm{~K}$ for $3.6 \times 10^{3} \mathrm{~s}$ in air or oxygen atmosphere. These doped $\mathrm{TiO}_{2}$ powders were pulverized in ethanol with a planetary 


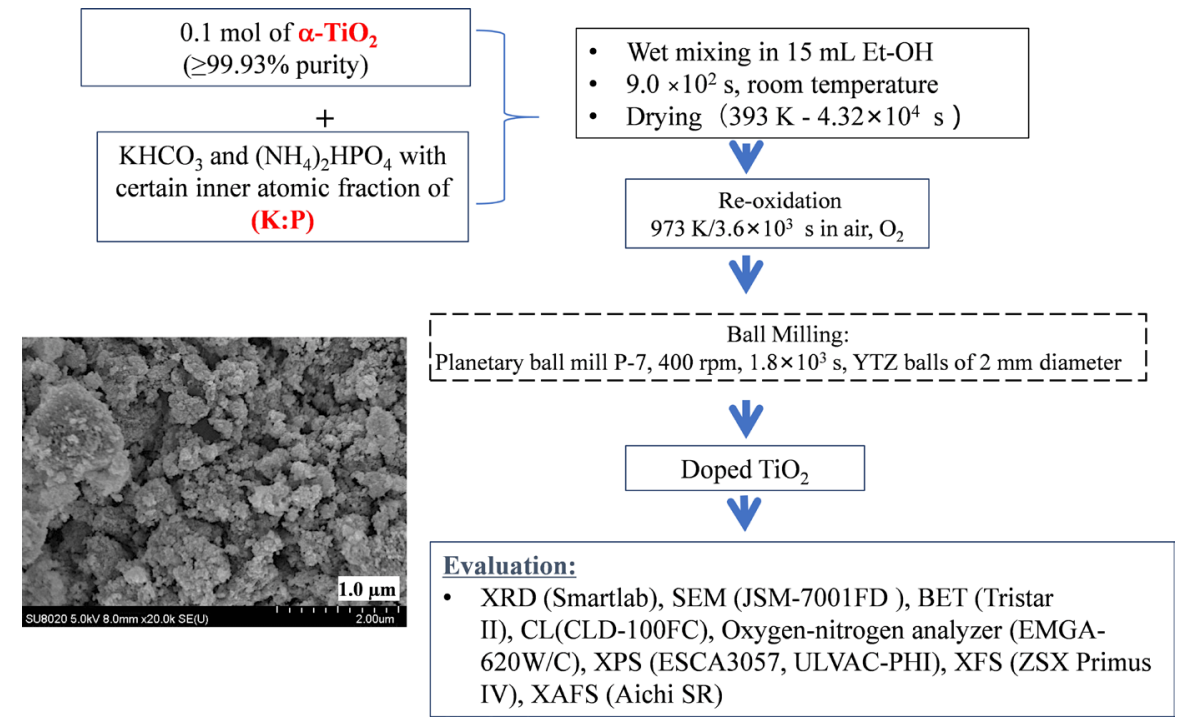

Figure 1. Flowchart of preparation and evaluation of $\mathrm{K}$ and $\mathrm{P}$ doped anatase $\mathrm{TiO}_{2}$. SEM photo shows the starting material of $a-\mathrm{TiO}_{2} \mathrm{~W}-4037$, BET surface area of $S_{\mathrm{A}}=55.1 \mathrm{~m}^{2} \cdot \mathrm{g}^{-1}$, theoretical density $D_{\mathrm{x}}=3.895 \mathrm{Mg} \cdot \mathrm{m}^{-3}$, particle size of $P_{\mathrm{s}}=0.0280 \mu \mathrm{m}$.

Table 1. The sample numbers of $\mathrm{TiO}_{2}$ doped with various amount of $\mathrm{K}$ and $\mathrm{P}$.

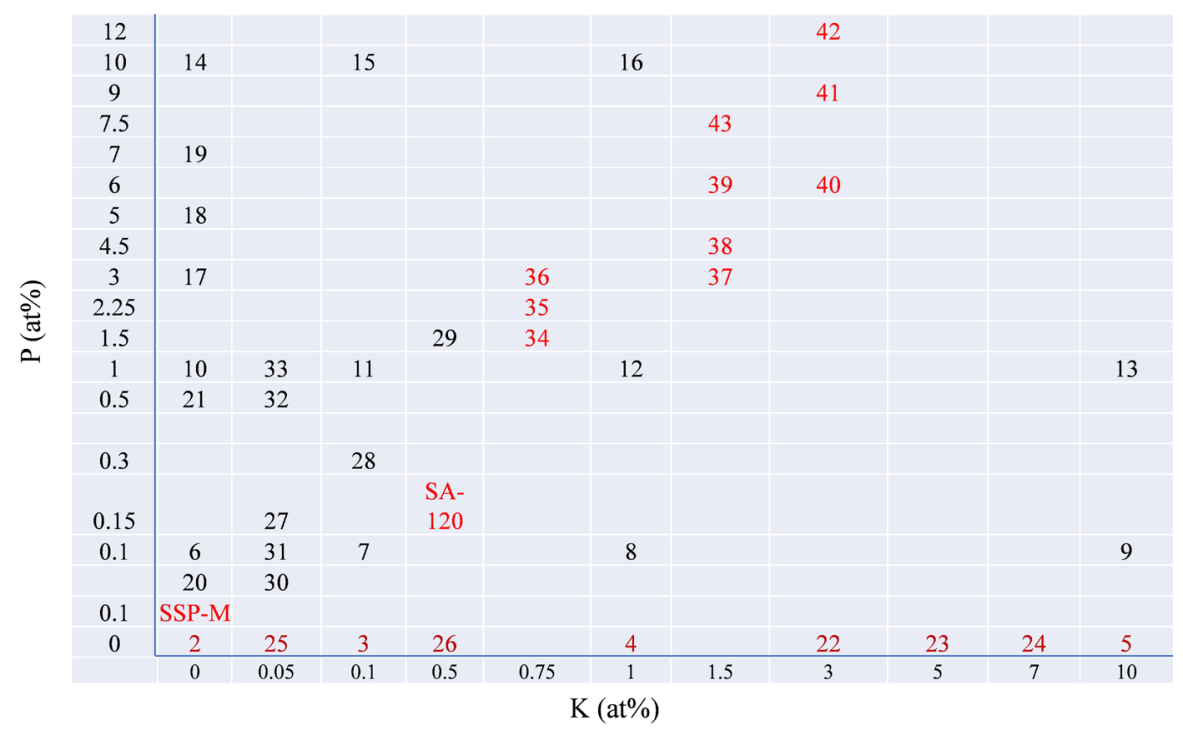

$(\mathrm{K}, \mathrm{P})=\mathrm{SSP}-\mathrm{M}(0,0.045), \quad \mathrm{SA}-120(0.085,0.113)$ at $\%$

ball milling apparatus (P-7, Fritsch Japan, Yokohama, Japan) for $1.8 \times 10^{3} \mathrm{~s}(30$ min) using yttria-stabilized tetragonal $\mathrm{ZrO}_{2}(\mathrm{YTZ})$ balls with a diameter of $2.0 \times$ $10^{-3} \mathrm{~m}(2.0 \mathrm{~mm} \phi)$, at a rotating speed of 6.67 round per sec (400 round per minute rpm; centrifugal force about $11 \mathrm{G}$, gravitation acceleration unit) under the ratio of the powder, YTZ balls, and ethanol were $1.0 \times 10^{-3} \mathrm{~kg}: 1.0 \times 10^{-2} \mathrm{~kg}: 1.0$ $\times 10^{-5} \mathrm{~m}^{3}(10 \mathrm{~mL})$.

\subsection{Evaluation}

\subsubsection{Physicochemical Property}

X-ray diffraction (XRD; Smartlab, Rigaku, Tokyo, Japan) analysis using $\mathrm{CuKa}$ 
radiation (wavelength of $0.15418 \mathrm{~nm}$ ) with a graphite monochromator was utilized for the crystalline phases and lattice parameter determinations. Microstructural observation with a field emission-type scanning electron microscope (FE-SEM; SU8020, Hitachi High-Technologies Corporation, Tokyo, Japan) and a transmission electron microscope (TEM, JEM-2100F, JEOL, Tokyo, Japan) equipped with energy-dispersive X-ray spectroscopy (EDS, JED-2300/F, JEOL). BET surface areas $S_{\mathrm{A}}$ of powders were measured using an automatic surface area and porosimetry analyzer (Tristar II, Micromeritics, Japanese agency Shimadzu, Kyoto, Japan) at room temperature. X-ray photoelectron spectroscopy (XPS) or electron spectroscopy for chemical analysis (ESCA) (ESCA3057, ULVAC-PHI. Inc., Chigasaki, Kanagawa, Japan) was utilized to analyze the surface chemical state of $\mathrm{K}$ and $\mathrm{P}$ in $\mathrm{TiO}_{2}$ powders. A monochromatic $\mathrm{AlKa} \mathrm{X}$-ray source (1486.6 $\mathrm{eV}$ ) was used and operated at $150 \mathrm{~W}$ in a pressure of $1.333 \times 10^{-12} \mathrm{~Pa}$. All the binding energies were referenced to the $\mathrm{Au}_{4 \mathrm{f} 7 / 2}$ peak located at $84.2 \mathrm{eV}$ attributed to the sputtered-Au on the surface. Fourier transform infrared spectroscopy (FT-IR, IRAffinity, Shimadzu) was performed under the following conditions; measuring method was attenuated total reflection (ATR, MIRacle 10, Shimadzu) with the resolution capacity of $4.0 \mathrm{~cm}^{-1}$, cumulated number is 20 , measuring wavenumber domain was $600-4000 \mathrm{~cm}^{-1}$ at room temperature. The local chemical structure around metal ions in anatase $\mathrm{TiO}_{2}$ crystalline structure had also been investigated by extended X-ray absorption fine structure (EXAFS) and $\mathrm{X}$-ray absorption near edge structure (XANES) both of which were performed at Aichi synchrotron radiation research center. The storage ring was operated at the ring-energy of $1.2 \mathrm{GeV}$ and a stored current of $300 \mathrm{~mA}$. Data were collected in transmission mode with two flat $\mathrm{Si}$ (311) crystals as a monochromator with a $\mathrm{RH}$-coated double mirror $(0.8 \mathrm{mrad})$ to reject the higher harmonics. The EXAFS data were processed using the computer program "Athena". The EXAFS functions were Fourier-transformed (FT) in the region $0.4-0.9 \mathrm{~nm}^{-1}$ to obtain the radial structure function (RSF). These were powerful tools for studying interatomic bonding- and electronic-states, and can provide information on the structure of a metal and an oxide ion, and/or a reactant. However, the local structure around $\mathrm{K}$ and $\mathrm{P}$ ions in $\mathrm{TiO}_{2}$ crystal were not well known. Instrument and attachment, integrating sphere: ISR-2200 and UV-Vis spectroscopy: UV-2400PC, were used for the band gap $E_{\mathrm{g}}$ measurement. The values of $E_{\mathrm{g}}$ of $a-\mathrm{TiO}_{2}$ powders were estimated by measuring reflectance spectrum intensity and transformed into absorbing spectrum intensity using Kubelka-Munk transformation [36].

The $\mathrm{pH}$ dependence of the emission of reactive oxygen species (ROS) which is emitted from the surface of $a-\mathrm{TiO}_{2}$ immersed in various $\mathrm{PH}$ buffer solutions was analyzed using an electron spin resonance apparatus (ESR, JES FA-100, JEOL) with the maximum magnetic field of $0.65 \mathrm{~T}$. Among all ROS, as hydroxyl radical $\mathrm{OH}$. has the highest redox potential (2.8 V/SHE) and the longest life-time [37], this ROS is the most powerful to kill bacteria. At ESR measurement, [power: 4 $\mathrm{mW}$, central field: $328.3 \mathrm{mT}$, sweeping width: $1 \pm 10 \mathrm{mT}$, sweeping time: $30 \mathrm{~s}$, modular width: $0.3 \times 1 \mathrm{mT}$, time constant: $0.03 \mathrm{~s}$, at $293 \mathrm{~K}$ ], 5,5-dimethyl- 
1-pyrroline-N-oxide (DMPO) was used as a scavenger in order to trap OH. As DMPO traps both hydroxyl radical and superoxide oxygen anion $\mathrm{O}_{2}{ }^{-}$, the reaction of $\mathrm{O}_{2} \cdot{ }^{-}$with DMPO is very slow when compared with $\mathrm{OH} \cdot$ and the collected radical is less stable than the one formed with $\mathrm{OH}$. Moreover, a small fraction is subsequently decomposed into DMPO-OH.

\subsubsection{Evaluation of Reactive Oxygen Species (ROS)}

Chemiluminescence $(\mathrm{CL})$ of $\mathrm{TiO}_{2}$ powders $(10 \mu \mathrm{mol})$ in a $2.5 \times 10^{-7} \mathrm{~m}^{3}(0.25$ $\mathrm{mL})$ aqueous luminol solution with a concentration of $5.0 \times 10^{-9} \mathrm{~mol} \cdot \mathrm{m}^{-3}(5.0$ $\mu$ mol. $\left.\mathrm{L}^{-1}\right)$ mixed with $3.0 \times 10^{-6} \mathrm{~m}^{3}(3.0 \mathrm{~mL})$ carbonic acid buffer solution $(\mathrm{NaOH} /$ $\left.\mathrm{NaHCO}_{3}, \mathrm{pH}=10.8\right)$ was observed under dark conditions using a CL detector (CLD-100FC, Tohoku Electronic Industrial Co., Ltd., Sendai, Japan). After dropping the luminol solution in a $1.2 \times 10^{2} \mathrm{~s}^{\prime}$ warming up of the detector, the intensity of CL was integrated between $1.2-6.0 \times 10^{2} \mathrm{~s}$. Chemiluminescence (CL) with scavengers such as, 2-5 dimethyl furan (for singlet oxygen, ${ }^{1} \mathrm{O}_{2}$, Fuji-film Wako Pure Chemical Co., Ltd., Osaka, Japan), nitro blue tetrazolium (for superoxide, $\cdot \mathrm{O}_{2}^{-}$, Nacalai Tesque Chemicals), 2-propanol (for hydroxyl radical, OH., Nacalai Tesque Chemicals), and riboflavin (for hydrogen per oxide, $\mathrm{H}_{2} \mathrm{O}_{2}$, Fuji-film Wako Pure Chemical Co., Ltd.) measurements were performed at room temperature in the dark to identify the reactive oxygen species (ROS) of $\mathrm{TiO}_{2}$ powders.

\section{Results and Discussion}

Figure 2 shows SEM photographs of a) No. 18: $\mathrm{TiO}_{2}$ doped with 5.0 at\% $\mathrm{P}$ heated at $973 \mathrm{~K}$ for $3.6 \times 10^{3} \mathrm{~s}$ in air with a surface area of $S_{\mathrm{A}}=35.6 \mathrm{~m}^{2} \cdot \mathrm{g}^{-1}$, here No.18 is the sample number displayed in Table 1, afterward the same manner, b) No. 23: 5.0 at $\% \mathrm{~K}$ doped $\mathrm{TiO}_{2}$ with $S_{\mathrm{A}}=29.0 \mathrm{~m}^{2} \cdot \mathrm{g}^{-1}$, c) No. 35: $\mathrm{K}: \mathrm{P}=0.75: 2.25$ at $\%(\mathrm{~K} / \mathrm{P}$ $=1 / 3$ atomic ratio) doped $\mathrm{TiO}_{2}$ with $S_{\mathrm{A}}=28.3 .0 \mathrm{~m}^{2} \cdot \mathrm{g}^{-1}$, and d) No. 38: $\mathrm{K}: \mathrm{P}=$ 1.5:4.5 at $\%(\mathrm{~K} / \mathrm{P}=1 / 3$ atomic ratio $) \mathrm{TiO}_{2}$ doped with $S_{\mathrm{A}}=21.0 \mathrm{~m}^{2} \cdot \mathrm{g}^{-1} \mathrm{~g}$. From these $S_{\mathrm{A}}$ values, as they showed also anatase phase confirmed by XRD as will be described later, their particle sizes $P_{\mathrm{s}}$ were calculated to be $P_{\mathrm{s}}(\text { No. } 2)^{1}=0.103$ $\mu \mathrm{m}, P_{\mathrm{s}}($ No. 18$)=0.0433 \mu \mathrm{m}, P_{\mathrm{s}}\left(\right.$ No. 23) $=0.0531 \mu \mathrm{m}, P_{\mathrm{s}}($ No. 35) $=0.0544 \mu \mathrm{m}$ and $P_{\mathrm{s}}($ No. 35$)=0.0734 \mu \mathrm{m}$ using the same theoretical density of anatase $D_{\mathrm{x}}=$ $3.895 \mathrm{Mg} \cdot \mathrm{m}^{-3}$ (PDF\#21-1272). They were nanoparticle powders (NPS). It is interesting that after heating, a small amount of $\mathrm{P}$ doped sample gave high $S_{\mathrm{A}}$ value $\left(35.6 \mathrm{~m}^{2} \cdot \mathrm{g}^{-1}\right)$ and decreased gradually with increasing the content of $\mathrm{K}$ or/and $\mathrm{P}$, from 35.6 to $21.0 \mathrm{~m}^{2} \cdot \mathrm{g}^{-1}$. It is easily noticed that $\mathrm{P}$ addition has much effect to suppress the particle growth at $973 \mathrm{~K}$.

The effect of P-doping on the decrement of $P_{\mathrm{s}}$ and increment of $S_{\mathrm{A}}$ agreed well with the previous results reported by Yu et al. [30] and Shi et al. [32]. About the other K-doping effects have been described by Chen et al. [25] and Yan et al. [27]; the former pointed out that decrease in $S_{\mathrm{A}}$ with more than 4.6 at $\% \mathrm{~K}$, on the other hand the latter increase in $S_{\mathrm{A}}$ with a 3 at\% $\mathrm{K}$ addition.

${ }^{1}$ No. 2 sample was the powder without $\mathrm{K}$ and $\mathrm{P}$ addition, which was heated at $973 \mathrm{~K}$ for $3.6 \times 10^{3} \mathrm{~s}$ in air as a reference. 

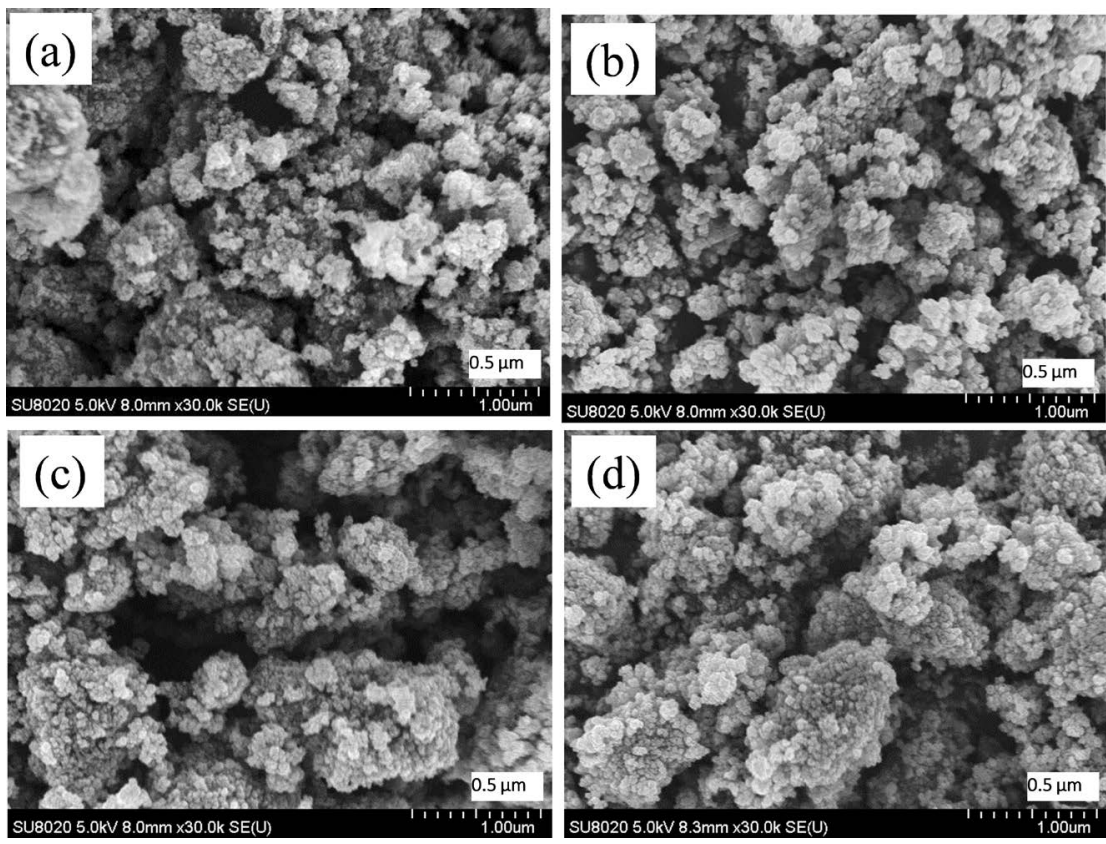

Figure 2. SEM photographs of $\mathrm{K}$ and $\mathrm{P}$ doped anatase $\mathrm{TiO}_{2}$, No. of samples are shown in Table 1: (a) No. 18, K:P = 0:5, $S_{\mathrm{A}}=35.6 \mathrm{~m}^{2} \cdot \mathrm{g}^{-1}, P_{\mathrm{s}}=0.0433 \mu \mathrm{m}$, (b) No. 23, K:P = 5:0 at\%, $S_{\mathrm{A}}=29.0 \mathrm{~m}^{2} \cdot \mathrm{g}^{-1}, P_{\mathrm{s}}=0.0531 \mu \mathrm{m}$, (c) No. 35, K:P $=0.75: 2.25, S_{\mathrm{A}}=28.3 \mathrm{~m}^{2} \cdot \mathrm{g}^{-1}, P_{\mathrm{s}}=0.0544$ $\mu \mathrm{m}$, and (d) No. 38, K:P = 1.5:4.5, $S_{\mathrm{A}}=21.0 \mathrm{~m}^{2} \cdot \mathrm{g}^{-1}, P_{\mathrm{s}}=0.0734 \mu \mathrm{m}$.

Figure 3 shows XRD patterns of the representative $\mathrm{TiO}_{2}$ powders without and with a small amount of K and P; a) No. 18 (5.0 at\% P), b) No. 23 (5.0 at\% K), c) No. 35 (K:P = 0.75:2.25 at\%), and d) No. 38 ( $\mathrm{K}: \mathrm{P}=1.5: 4.5$ at\%). There were no other phases except anatase, even though the diffraction intensity of anatase was much scattered. This X-ray diffraction peak broadening caused by decreasing both crystallinity and crystallite sizes is the same result as Chen et al. [25] and Yan et al. [27].

Then the lattice parameters $a$ and $c$ of anatase phase were estimated by the method of least squares refinement using $\mathrm{Si}$ as an internal standard. As the amount of $\mathrm{P}$ is much higher than that of $\mathrm{K}$, the lattice parameter changes in both $a$ and $c$ were evaluated as a function of input P. Figure 4 shows, (i) $a$ of the combined $\left(\mathrm{K} / \mathrm{P}=1 / 3\right.$ atomic ratio) added $a-\mathrm{TiO}_{2}$ powders, (ii) $a$ of the single addition of $\mathrm{P}$, (iii) $c$ of the single addition of $\mathrm{P}$, and (iv) $c$ of the combined (1.K+3.P; $\mathrm{K} / \mathrm{P}=1 / 3$ atomic ratio) addition are displayed. It is clear that the single addition gives the decrease in both $a$ and $c$ values. This might be explained due to the small ionic radius $r$ of $\mathrm{P}^{5+}$ with the coordination IV, $r\left(\mathrm{P}^{5+}\right)_{\mathrm{VI}}=0.038 \mathrm{~nm}$, in comparison with $r$ of $\mathrm{Ti}^{4+}, r\left(\mathrm{Ti}^{4+}\right)_{\mathrm{VI}}=0.0605 \mathrm{~nm}$. However, (i) $a$ and (iv) $c$ values of the combined addition of $(1 \cdot \mathrm{K}+3 \cdot \mathrm{P})$ are almost constant; this could be explained by that the average $r$ of $(1 \cdot \mathrm{K}+3 \cdot \mathrm{P})$, calculated from $r\left(\mathrm{~K}^{+}\right)_{\mathrm{VI}}=0.138 \mathrm{~nm}$, and $r\left(\mathrm{P}^{5+}\right)_{\mathrm{VI}}=0.038 \mathrm{~nm},[(0.138+3.0 .038) / 4=0.063 \mathrm{~nm}]$, is almost the same as $\mathrm{Ti}^{4+}$. These ionic radii values were reported by Shannon [38]. Furthermore, the combined addition could make it easy to dope into $a-\mathrm{TiO}_{2}$ lattice, because its average electric valence is +4 , the same as titanium. In addition, single addition of 

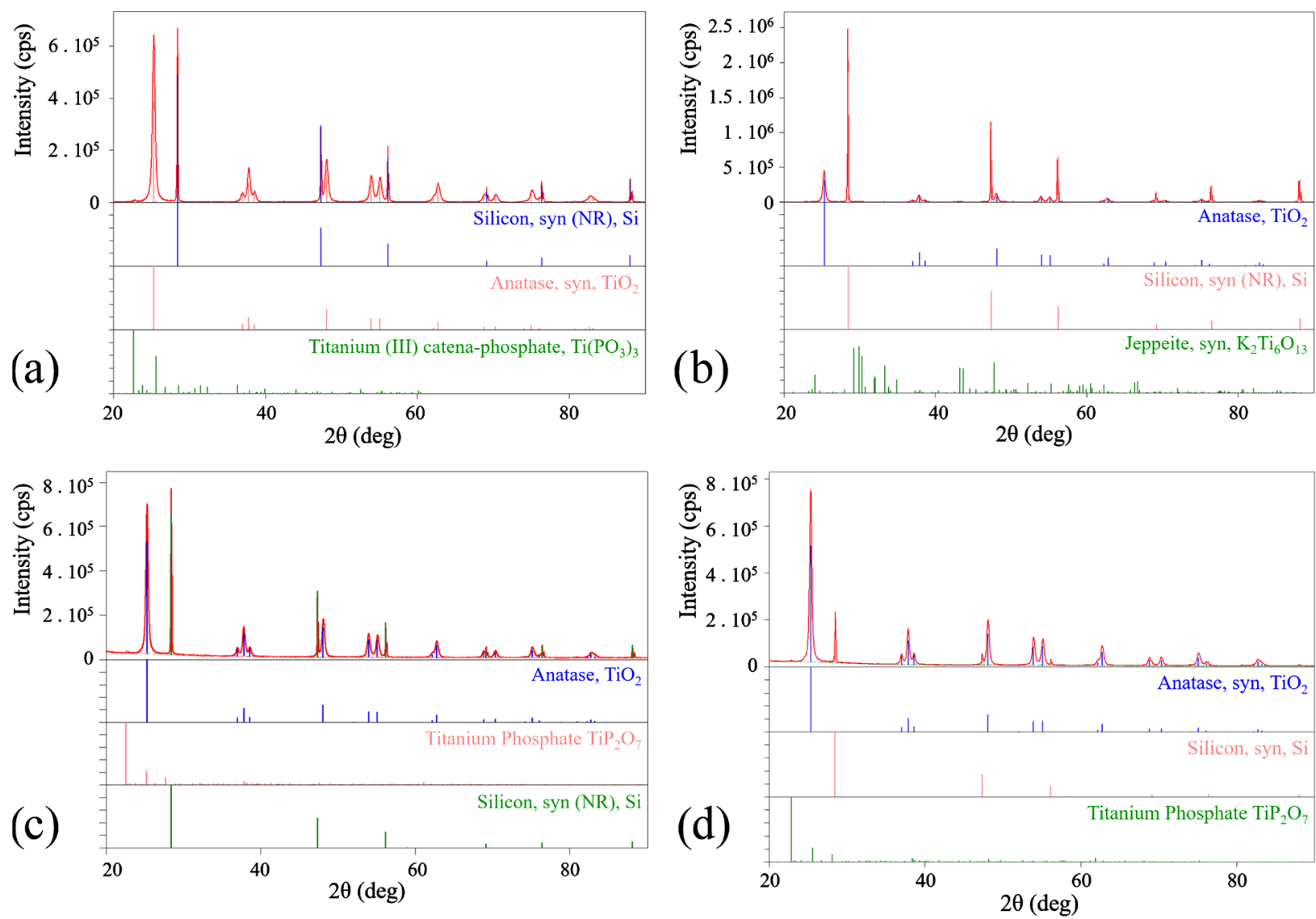

Figure 3. XRD patterns of (a) No. 18 (K:P = 0:5), (b) No. 23 (K:P = 5:0), (c) No. 35 (K:P = 0.75:2.25), and (d) No. 38 (K:P = 1.5:4.5).

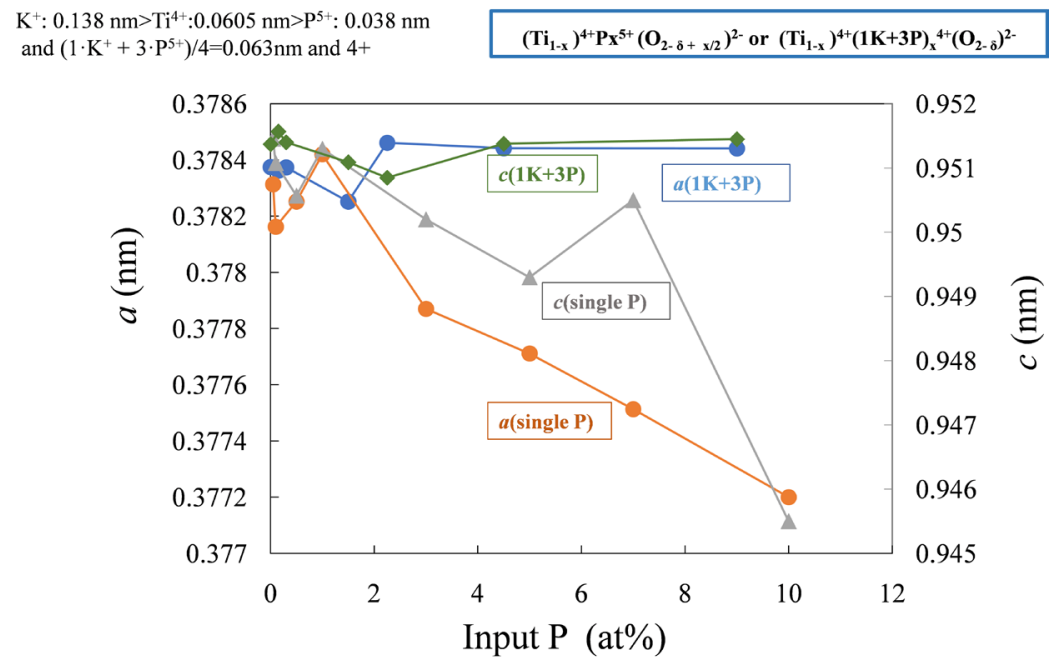

Figure 4. Lattice parameters of $a-\mathrm{TiO}_{2}$ doped with various contents of $\mathrm{P}$ (at $\left.\%\right)$.

$\mathrm{K}^{+}$and $\mathrm{P}^{5+}$ introduced the formation of oxygen excess and deficiency, respectively. These results are accordance with the previous studies that the solubility limit of $\mathrm{K}$ was around 0.2 at\% by impregnation method (Yildizhan et al., [28]), and a charge imbalance induced by $\mathrm{P}^{5+}$ resulted in the reduction of oxygen deficiency (Shi et al., [32]). 
As the amount of chemiluminescence CL corresponding to that of ROS which can disinfect bacteria, the CL emitted from the surface of $a-\mathrm{TiO}_{2}$ was observed under dark conditions as described before.

At first as preliminary experiment, ROS from various co-doped powders prepared by heating in air was investigated; their results were displayed in Figure 5. From the CL curves of No. $28(\mathrm{~K} / \mathrm{P}=0.1 / 0.3$ at\%) heated at 973, 1073, and 1173 $\mathrm{K}$, it was confirmed that $973 \mathrm{~K}$ heating gave the highest CL. Then, the CL values of other co-doped powders such as No. 35 (K/P = 0.75/2.25 at\%), No.38 (1.5/4.5 at\%), and No. 41 (3.0/9.0 at\%), were investigated using CL-scavenger combined system; this system indicated which ROS was submitted from $a-\mathrm{TiO}_{2}$ powders. For example, the much reduction in CL intensity from No-scavenger to 2-popanol (scavenger for $\mathrm{OH} \cdot$ ) added samples, suggests that the ROS is hydroxyl radical $\mathrm{OH}$.

Then, the effect of the heat-treatment atmosphere during solid state reaction for doping was investigated. Figure 6 shows the CL values of various $a-\mathrm{TiO}_{2}$ as a function of input $\mathrm{P}$ content. After heating at $973 \mathrm{~K}$ for $3.6 \times 10^{3} \mathrm{~s}$ in oxygen, co-doped $(1 \cdot \mathrm{K}+3 \cdot \mathrm{P})$ a- $\mathrm{TiO}_{2}$ showed significantly high $\mathrm{CL}$ values comparing with those of other $\mathrm{K}$ or $\mathrm{P}$ single added samples heated in air at same conditions.

In order to research the inner structure of doped $\mathrm{TiO}_{2}$, XPS measurement has been performed. Figure 7 shows the spectra of (i) $\mathrm{TiO}_{2}, \mathrm{Ti}_{2 \mathrm{P} 1 / 2}, \mathrm{Ti}^{4+}{ }_{2 \mathrm{P} 3 / 2}$, (ii) $\mathrm{P}_{2 \mathrm{p}}$,

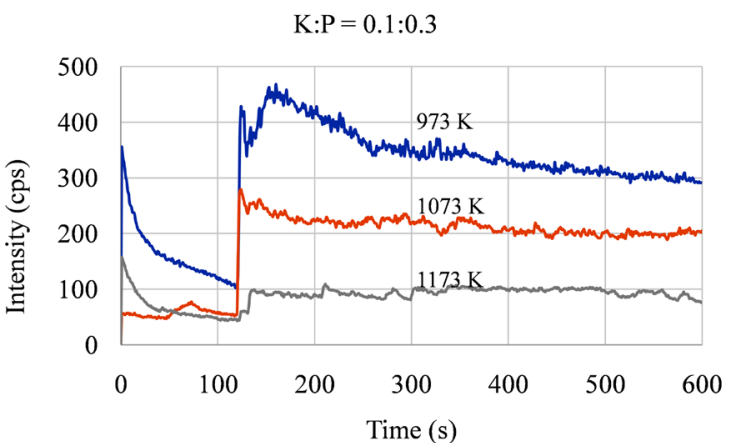

-No $28-700-$ No.28-800 - No.28-900

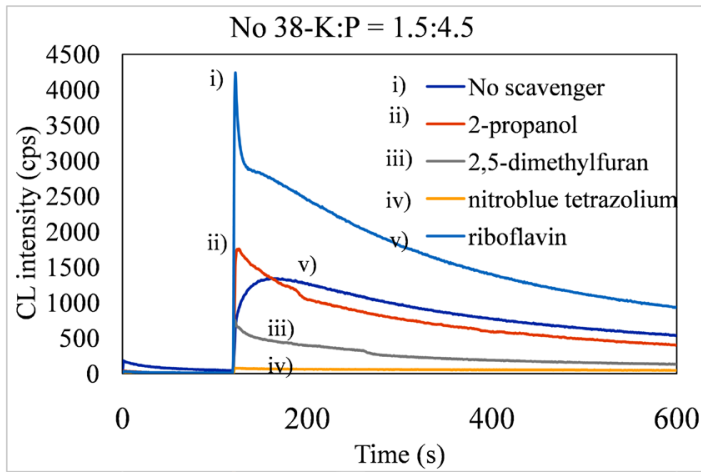

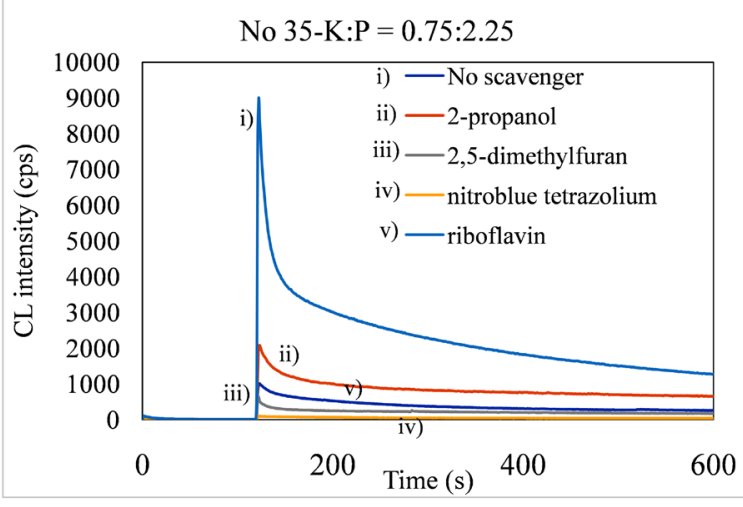

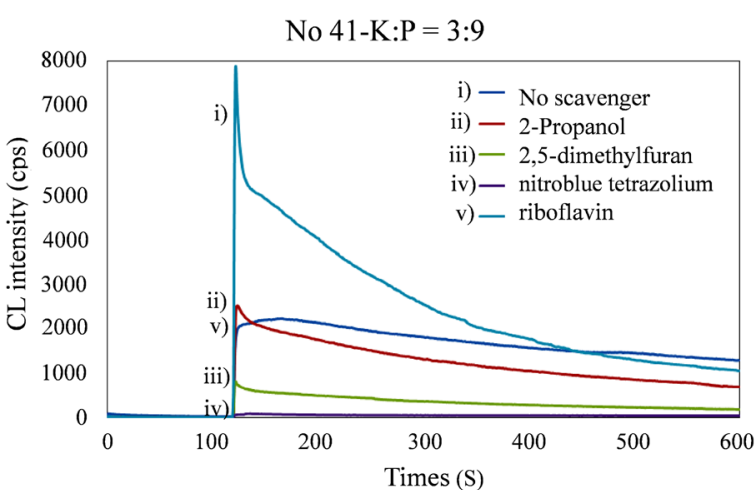

Figure 5. CL values of various $a-\mathrm{TiO}_{2}$ co-doped with $\mathrm{K}$ and $\mathrm{P}$; their atomic ratio is a constant of $1: 3$, varying $\mathrm{K} / \mathrm{P}=$ 0.1/0.3 (sample No. 28), 0.75/2.25 (No. 35), 1.5:4.5 (No. 38), and 3.0:9.0 (No. 41). 


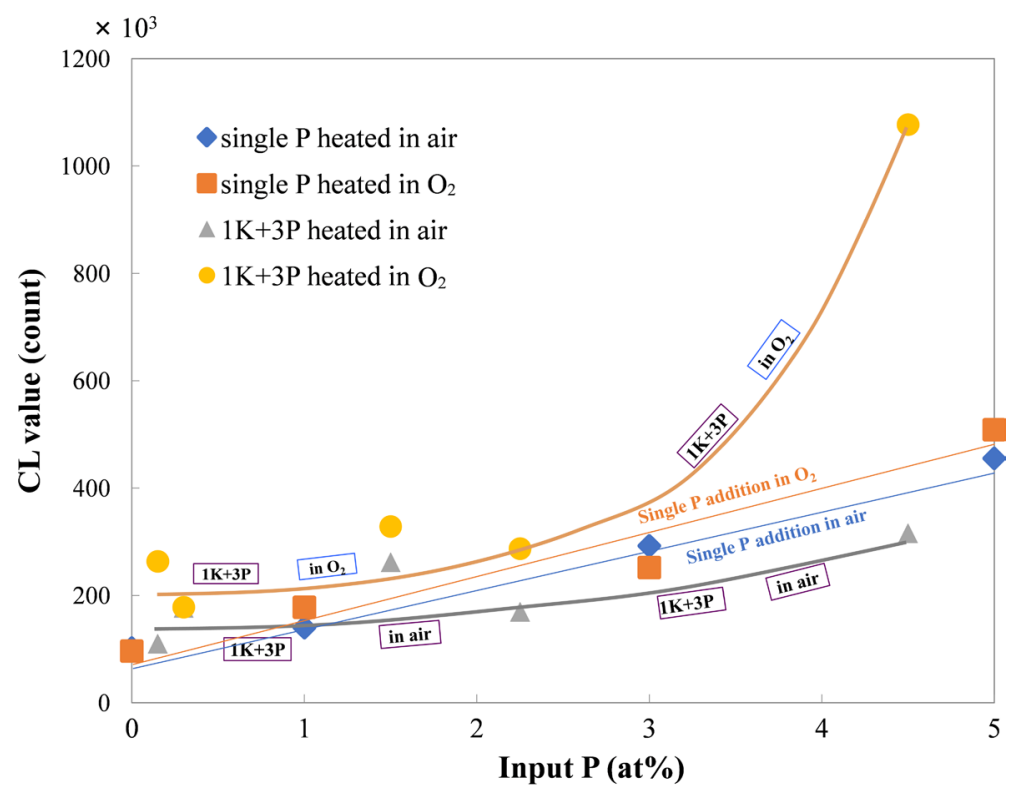

Figure 6. CL values of various single or co-doped $a-\mathrm{TiO}_{2}$ as a function of $\mathrm{P}$, which materials were heated at $973 \mathrm{~K}$ in air or $\mathrm{O}_{2}$ atmosphere.
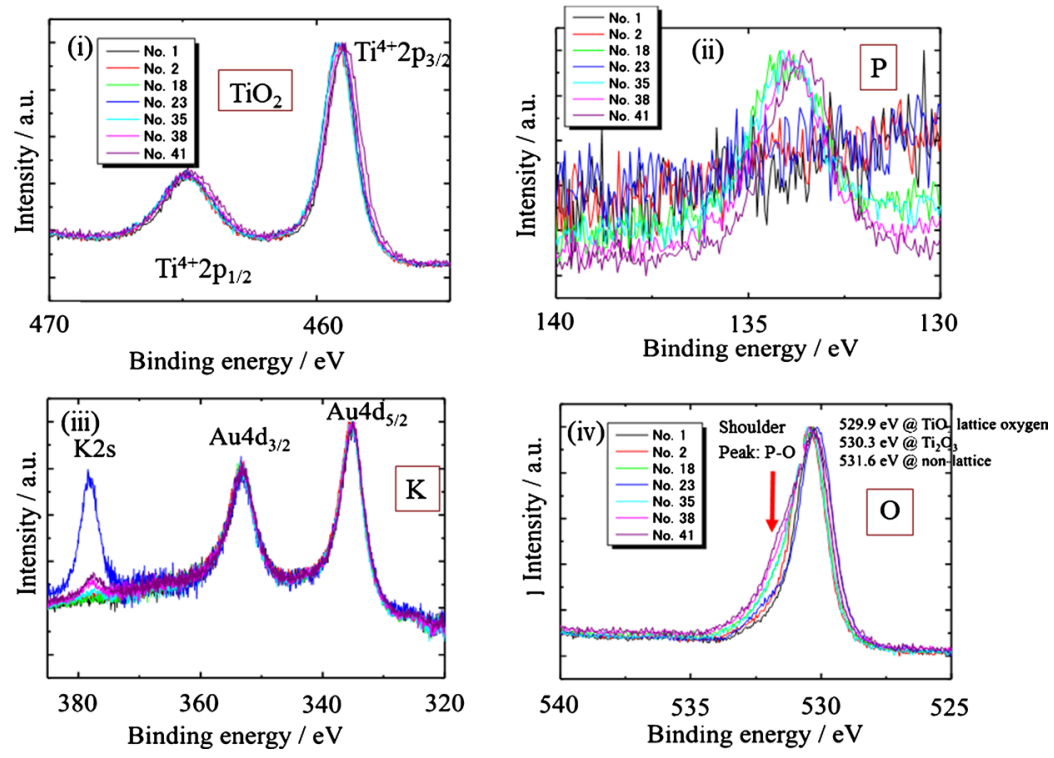

Figure 7. XPS spectra of $a-\mathrm{TiO}_{2}$ doped with various $\mathrm{K}$ and $\mathrm{P}$ prepared by heating in air, corresponding to (i) $\mathrm{TiO}_{2}$, (ii) $\mathrm{P}$, (iii) $\mathrm{K}$, and (iv) O. Here, No. 1, starting material, No. 2, non doped anatase, No. 18, K:P = 0:5, No. 23, K:P = 5:0, No. 35, $\mathrm{K}: \mathrm{P}=0.75: 2.25$, No.38, $\mathrm{K}: \mathrm{P}=1.5: 4.5$, No.41, K:P = 3:9 at $\%$.

(iii) $\mathrm{K}_{2 s}$, and (iv) $\mathrm{O}_{1 s}$ of various $a-\mathrm{TiO}_{2}$, such as No. 1 (as-received $a-\mathrm{TiO}_{2}$ ), No. 2 (973 K-heated No. 1), and No. 18, 23, 35, 38 and 41 samples which are denoted in Table 1. From these XPS spectra, there is not so much difference among all, except for $\mathrm{O}_{1 \mathrm{~s}}$ spectra in (iv). In these spectra, the peaks of $529.9 \mathrm{eV}$ @ $\mathrm{TiO}_{2}$ lattice oxygen, $530.3 \mathrm{eV} @ \mathrm{Ti}_{2} \mathrm{O}_{3}$, and $531.6 \mathrm{eV} @$ non-lattice are mixed at around $530 \mathrm{eV}$. However, the weak shoulder peaks of $\mathrm{P}$ doped samples (No. $18,35,38,41)$ are observed around $532 \mathrm{eV}$; these could be attributed to $\mathrm{O}$ in 


\section{O-H or P-O.}

Then, we measured FT-IR spectra of the same doped anatase samples to check the presence of $\mathrm{O}-\mathrm{H}$ and $\mathrm{P}-\mathrm{O}$. As shown in Figure 8, it was clearly detected phosphate group $\left(\mathrm{PO}_{4}^{3-}\right)$ around $1000 \mathrm{~cm}^{-1}$. However, $\mathrm{OH}$ group $\left(\mathrm{OH}^{-}\right)$was not found. Furthermore, the inner structure of doped $\mathrm{TiO}_{2}$ was studied by using XAFS [39]; the results are presented in Figure 9; (i) local chemical environment around $\mathrm{K}^{+}$(XANES), all the spectra except for $\mathrm{K}_{2} \mathrm{SO}_{4}$ (the reference substance) were measured by partial fluorescence yield (PFY) mode. From upper the $2^{\text {nd }}$ to

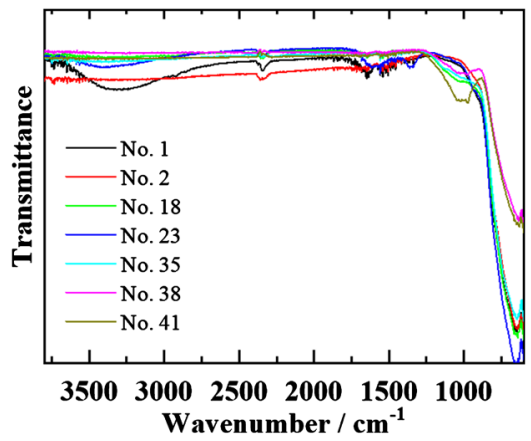

Figure 8. FT-IR spectra of $a-\mathrm{TiO}_{2}$ doped with various $\mathrm{K}$ and $\mathrm{P}$ prepared by heating in air; No. corresponding to the samples shown in Table 1.
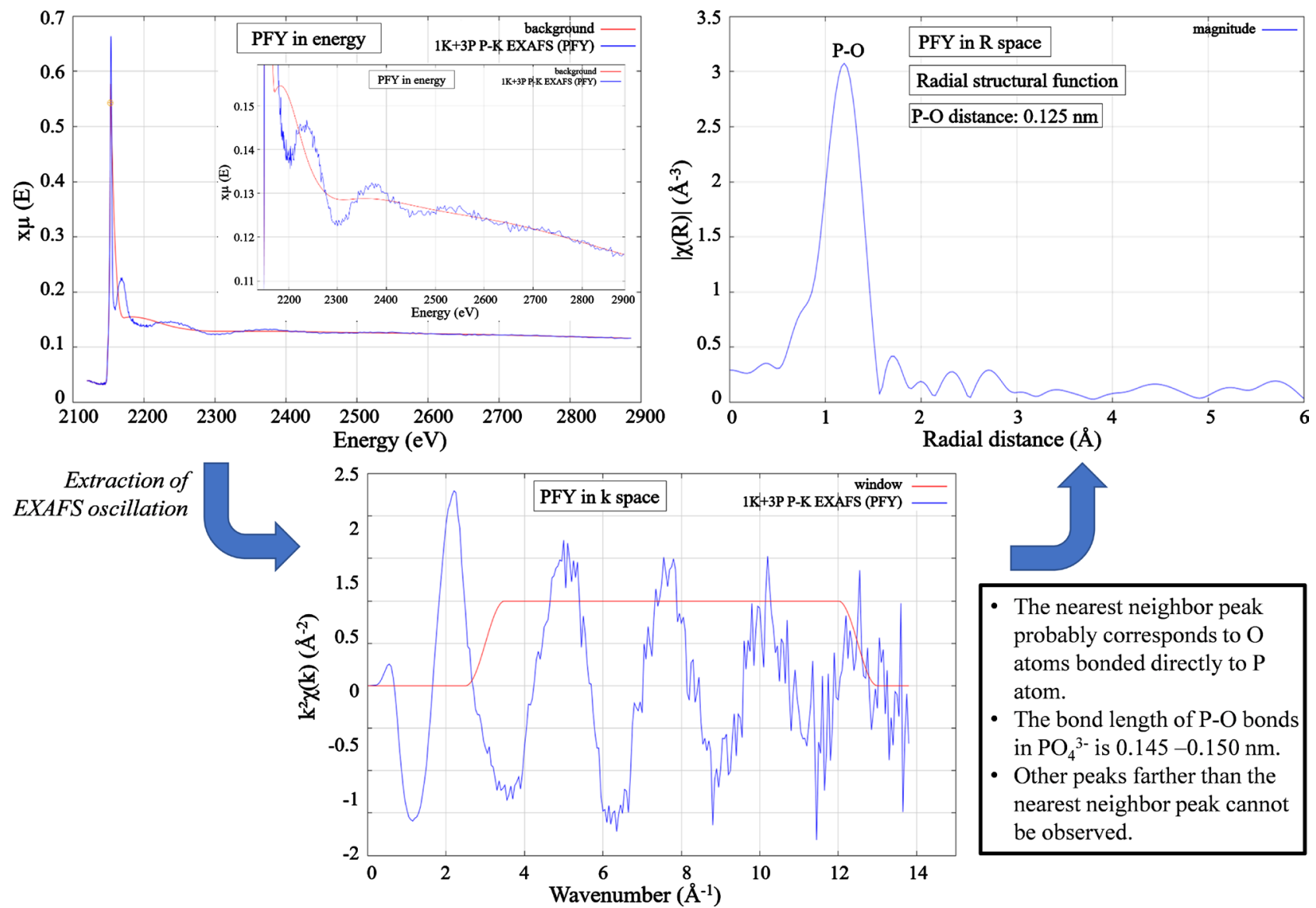

- The nearest neighbor peak probably corresponds to $\mathrm{O}$ atoms bonded directly to $\mathrm{P}$ atom.

- The bond length of $\mathrm{P}-\mathrm{O}$ bonds in $\mathrm{PO}_{4}{ }^{3-}$ is $0.145-0.150 \mathrm{~nm}$.

- Other peaks farther than the nearest neighbor peak cannot be observed.

Figure 9. EXAFS of $(1.5$ at $\% \cdot \mathrm{K}+4.5$ at $\% \cdot \mathrm{P})$ co-doped $a-\mathrm{TiO}_{2}$ prepared by heating in air. 
$5^{\text {th }}$ curves, 5 at $\% \mathrm{~K}, 1 \cdot \mathrm{K}+2 \cdot \mathrm{P}, 1 \cdot \mathrm{K}+3 \cdot \mathrm{P}, 1 \cdot \mathrm{K}+4 \cdot \mathrm{P}$ (here, $\mathrm{K}=0.75$ at $\left.\%\right)$ doped samples; small differences are seen for the peak at $\sim 3614 \mathrm{eV}$ and the shoulder structure in the higher energy side of the peak. And (ii) shows local chemical environment around $\mathrm{P}^{5+}$ (XANES), as the same as (i) in which all the spectra except for $\mathrm{Ca}_{3}\left(\mathrm{PO}_{4}\right)_{2}$ (the reference substance) were measured by PFY mode. $\mathrm{K}$-edge XANES spectrum of $\mathrm{P}$ elements in $\mathrm{P}$-doped $a-\mathrm{TiO}_{2}$ was very similar to single addition of 5 at $\% \mathrm{P}$ and compound addition. Therefore, the local chemical environment around $\mathrm{P}^{5+}$ is almost the same. EXAFS results of $\mathrm{P} \mathrm{K}$-edge spectrum of $\left(1 \cdot \mathrm{K}+3 \cdot \mathrm{P}, \mathrm{K}=0.75\right.$ at\%)-doped $a-\mathrm{TiO}_{2}$ are shown in Figure 10, Fourier transformation of K-range had been done from 0.3 to $1.25 \mathrm{~nm}$ (3.0 - $12.5 \AA$ ) (upper right side), then radial structural function (lower right side) was obtained. The distance between $\mathrm{P}-\mathrm{O}$ ions was considered to be shorter than the distance of $\mathrm{P}-\mathrm{O}$ in $\mathrm{PO}_{4}^{3-}$ i.e., from 0.145 to $0.15 \mathrm{~nm}$ (1.45 to $\left.1.50 \AA\right)$. However, the coupling distance, calculated based on the radial structure function obtained through Fourier transformation of EXAFS oscillation depends on a factor which called as phase factor. The details are still unknown because it is several orders of magnitude shorter than the actual coupling distance. Therefore, $\mathrm{O}$ was present in the nearest neighbor of $\mathrm{P}$, the same results reported by Shi et al. [32], and there was almost no ordering beyond that.

Then, the band structure of undoped and doped $a-\mathrm{TiO}_{2}$ were evaluated; their results are shown in Figure 11. These figures contain the function expressed as $\mathrm{F}(\mathrm{R}) * h v^{2}$ on the ordinate, here, $\mathrm{F}(\mathrm{R})$ is reflectance spectrum intensity, $h v(\mathrm{eV})$ (h: Planck constant, $v$ : wave number), and $\mathrm{eV}$ on the abscissa. Band gap $E_{\mathrm{g}}$ values were determined at the point of intersection between the line of tangency of each $\mathrm{F}(\mathrm{R}){ }^{*} h v^{2}$ curve and horizontal axis [40]. The $E_{\mathrm{g}}$ values of No. $38(\mathrm{~K}: \mathrm{P}=$
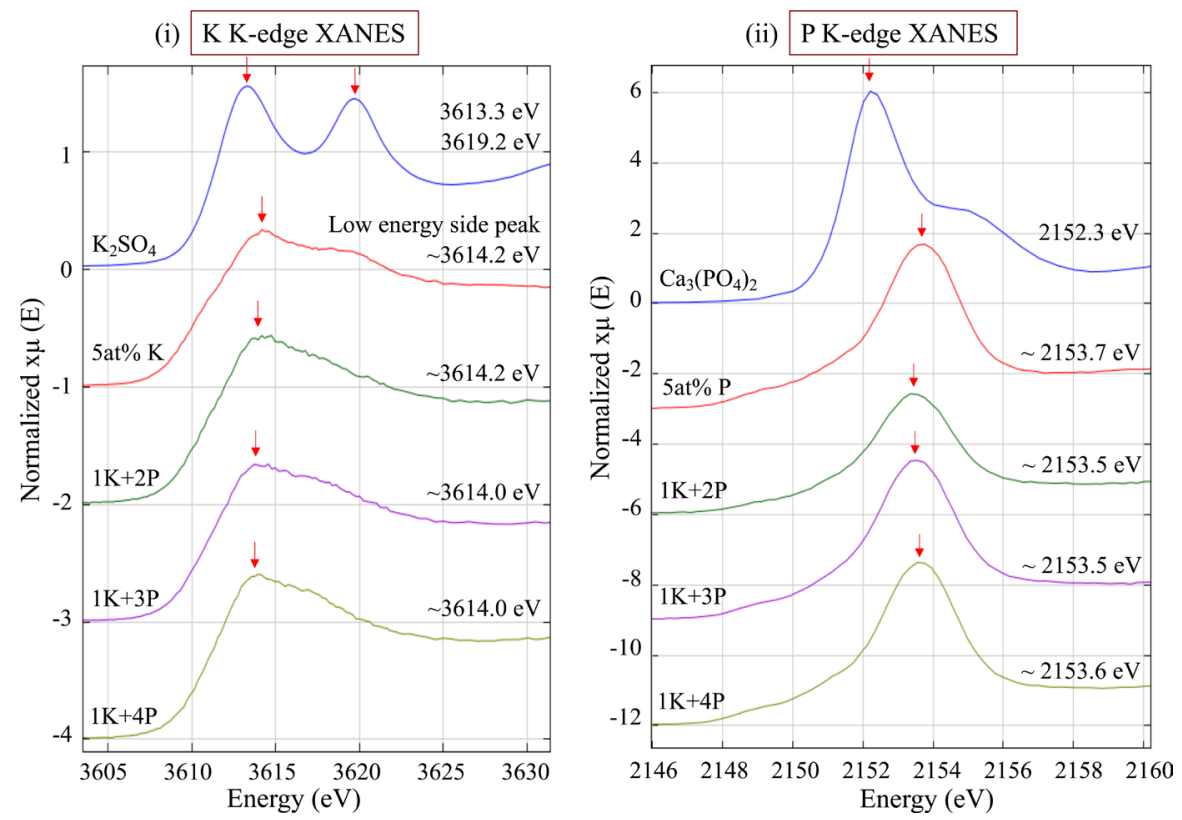

Figure 10. (i) K of K-edge XANES and (ii) P of K-edge XANES of $(1.5$ at $\% \cdot \mathrm{K}+4.5$ at $\% \cdot \mathrm{P})$ co-doped $a-\mathrm{TiO}_{2}$ prepared by heating in air. 

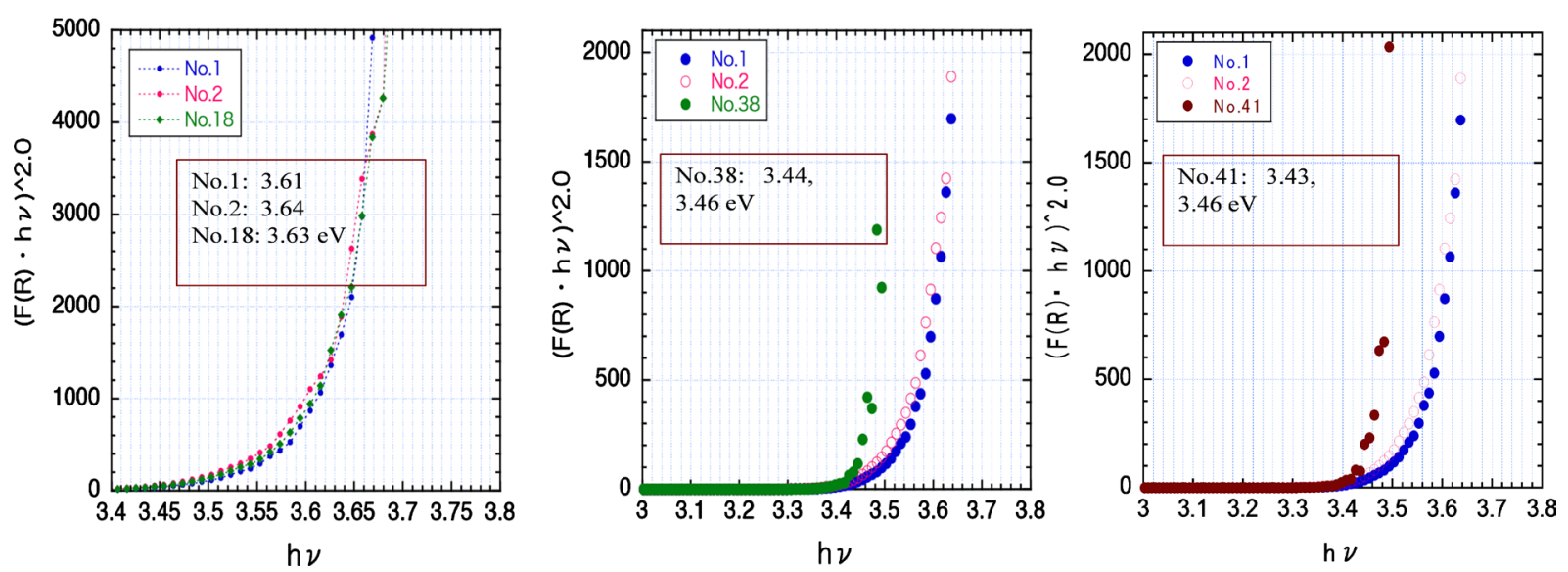

Figure 11. Band gap energy spectra of various $a-\mathrm{TiO}_{2}$; No. corresponding to the samples shown in Table 1.

1.5:4.5 at\%) $3.43 \mathrm{eV}$ and $41(\mathrm{~K}: \mathrm{P}=3: 9 \mathrm{at} \%) 3.46 \mathrm{eV}$ are almost the same. However, their energy levels were smaller than those ( 3.61 and $3.64 \mathrm{eV}$ ) of No. 1 and 2 , respectively; this might be due to the co-doping ( $\mathrm{K}$ and $\mathrm{P}$ ) effect (this phenomenon is usually called as red shift [26] [27] [41]. In addition, these values of pure anatase (No.1 and No. 2) are much higher than those (3.2 - $3.3 \mathrm{eV})$ reported for the previous papers on anatase; this could be originated from the high purity more than $99.92 \%$ and fine particle ( $P_{\mathrm{s}}$ of $0.028 \mu \mathrm{m}: 28 \mathrm{~nm}$ ). As it is very difficult to synthesize high purity/single-phase/fine anatase powder, for example, a very popular nano titanium dioxide powder $\left(P_{\mathrm{s}} \sim 30.3 \mathrm{~nm}, \mathrm{BET}: 50 \mathrm{~m}^{2} / \mathrm{g}\right)$, "P25" AEROXIDE', consists $80 \%$ anatase and $20 \%$ rutile phases. Therefore, the smaller band gap $\sim 3.2$ to $\sim 3.3 \mathrm{eV}$ for the anatase powder could be explained due to a small amount of impurities or double phases; because there are a few descriptions about their purity in the previous papers.

In the present study, pure $a-\mathrm{TiO}_{2}$ (No. 1 and heated 2) reveal only one $E_{\mathrm{g}}$ value, however, the doped samples have one or more energy gaps. Based on the viewpoints of $E_{\mathrm{g}}$, it is difficult to explain the reason why these anatase can produce ROS even under dark conditions, because if we presume that the photocatalytic property of $\mathrm{TiO}_{2}$, i) generation of electrons and holes in the conduction and valence bands, respectively, should be occurred by absorbing excitation energy which is greater than $E_{\mathrm{g}}(3.43-3.64 \mathrm{eV})$. ii) It has been explained that these excited electrons and holes can produce ROS, such as, $\mathrm{O}_{2}^{-}$from $\mathrm{O}_{2}$ and $\cdot \mathrm{OH}$ from $\mathrm{OH}^{-}$, respectively [42]. iii) However, as visible light energy, around 1.59 $3.10 \mathrm{eV}$, is lower than $E_{\mathrm{g}}$, visible light cannot excite the electrons in valence band of $\mathrm{K} \& \mathrm{P}$ doped anatase $\mathrm{TiO}_{2}$. iv) Therefore, the present $a-\mathrm{TiO}_{2}$ cannot submit much ROS under dark conditions. By the way, ultra violet wave (UV: $\lambda<387$ $\mathrm{nm}$ ) in solar light is only $5 \%$, then effect of UV excitation could be ignored.

TEM images were taken to investigate the particle sizes of co-doped $a-\mathrm{TiO}_{2}$. As shown in Figure 12, it can be seen that the prepared powders calcined in $\mathrm{O}_{2}$ atmosphere possess a spherical shape and nanoparticle sizes irrespective of ball-milling. The crystallinity of the powders may be confirmed from crisp pictures. Ball-milling effect on the CL amount is described as follows. 


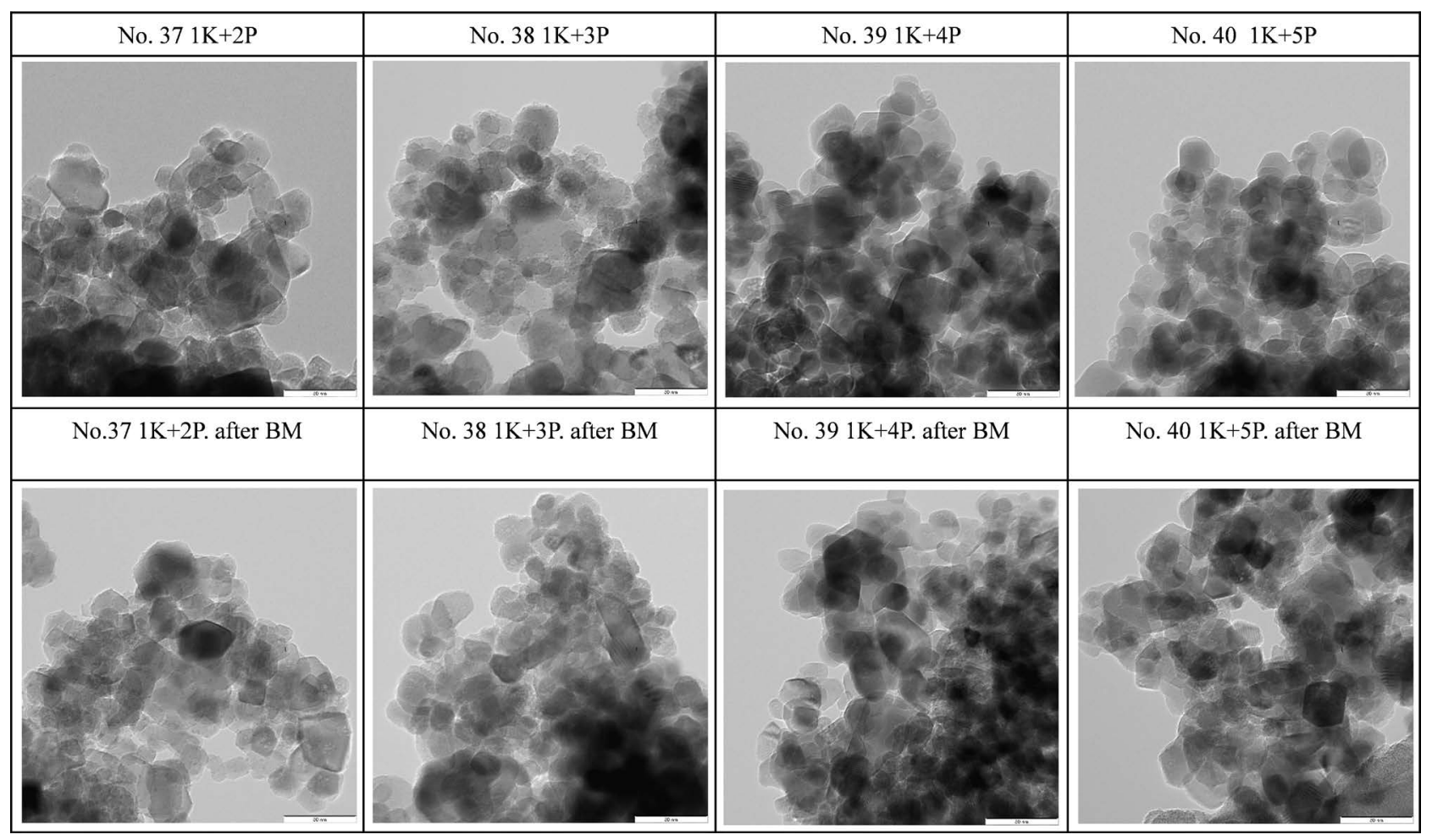

Figure 12 . TEM images of $1 \cdot \mathrm{K}+n \cdot \mathrm{P}(n=2,3,4$, here $\mathrm{K}=1.5$ at $\%)$, co-doped $a-\mathrm{TiO}_{2}$ prepared by heating in $\mathrm{O}_{2}$ followed by ball milling.

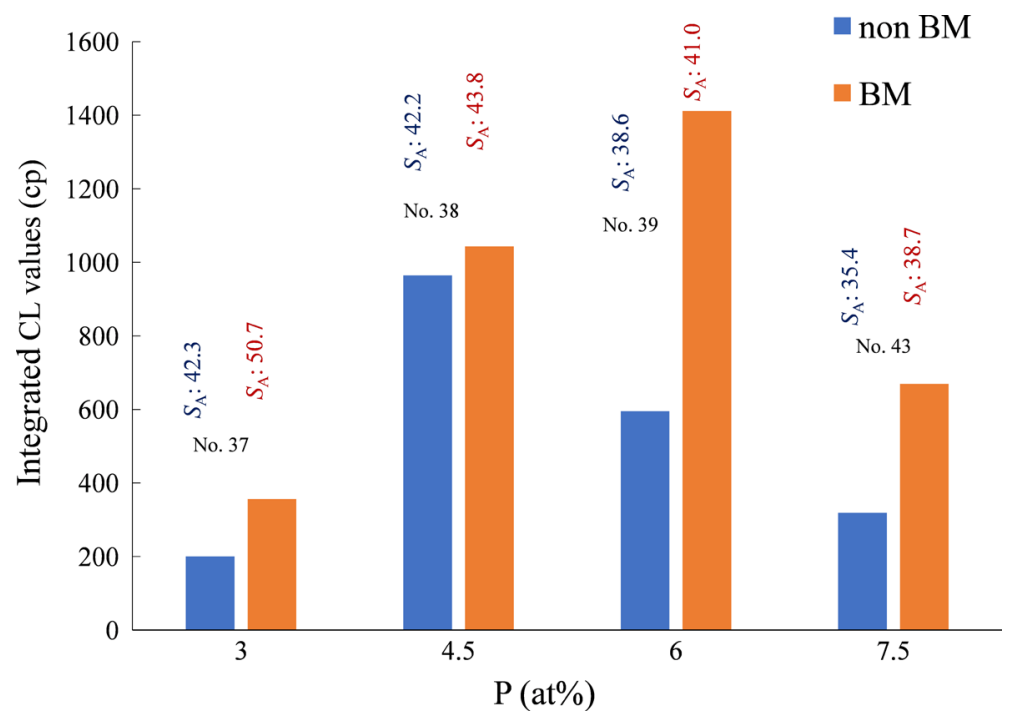

Figure 13. Integrated $\mathrm{CL}$ values of $1 \cdot \mathrm{K}+n \cdot \mathrm{P}(n=2,3,4$, here $\mathrm{K}=1.5$ at $\%)$ co-doped $a-\mathrm{TiO}_{2}$ prepared by heating in $\mathrm{O}_{2}$ (non $\left.\mathrm{BM}\right)$, and followed by ball milling (BM).

The integrated CL emission from the $\mathrm{K}$ and $\mathrm{P}$ co-doped $a-\mathrm{TiO}_{2}$ powders calcined in $\mathrm{O}_{2}$ at $973 \mathrm{~K}$ without and with ball-milling (BM) are represented in Figure 13. It appears that the $\mathrm{TiO}_{2}$ doped with 1.5 at $\% \mathrm{~K}$ and 4.5 at\% $\mathrm{P}$, i.e., $(1 \cdot \mathrm{K}+$ $3 \cdot \mathrm{P})$ shows the highest $\mathrm{CL}$ value, however, after $\mathrm{BM}, 1 \cdot \mathrm{K}+4 \cdot \mathrm{P}$ doped $a-\mathrm{TiO}_{2}$ revealed much higher CL value, that is, the peak-top of CL amount shifted to the higher P content. Here, the surface area $S_{\mathrm{A}}$ values of these powders are also indi- 
cated at the top of each bar graph. At first we thought that this increase might be originated from the increment in $S_{\mathrm{A}}$ introduced by BM. However, on the contrary to this expectation, the change in $S_{\mathrm{A}}$ is not so much. Therefore, a small amount of strain, which was introduced in the anatase lattice by ball-milling (BM), might have some effect on the submission of CL. Based on our preliminary experience to check the effect of ball-milling time on CL value, it was cleared that $1.8 \times 10^{3} \mathrm{~s}(30 \mathrm{~min}) \mathrm{BM}$ gave the best results and after much longer than it, the integrated CL values decreased, suggesting that too much strain could reduce the $\mathrm{CL}$ emission.

Then, different scavengers corresponding to each ROS were added to the highly efficient powder (No. 39, $1 \cdot \mathrm{K}+4 \cdot \mathrm{P}$ with BM) during CL measurement in order to determine which ROS was emitted. All CL values with scavengers were compared to those without scavenger. It can be seen in Figure 14 that all ROShydroxyl radical OH· (2-propanol, $\mathrm{PrOH}$, as scavenger [43] [44] [45]), superoxide radical $\cdot \mathrm{O}_{2}^{-}$(nitroblue tetrazolium, NBT [46] [47] and singlet oxygen ${ }^{1} \mathrm{O}_{2}$ (dimethylfluran, DMF [48]) —are emitted. By comparing i) (No. 39) with iv) $($ No. $39+\mathrm{PrOH})$, and v) $($ No. $39+\mathrm{BM})$ with viii) $($ No. $39+\mathrm{BM}+\mathrm{PrOH}) \mathrm{CL}$ curves, hydroxyl radical $\mathrm{OH}$ - seems to be the least emitted ROS, whereas superoxide radical $\cdot \mathrm{O}_{2}^{-}$is emitted the most by comparing i) (No. 39) with iii) (No. 39 + NBT), and v) (No. $39+$ BM) with vii) (No. $39+$ BM + NBT) CL curves. Regarding singlet oxygen ${ }^{1} \mathrm{O}_{2}$, its emission was proved by comparing i) (No. 39) with ii) (No. 39+DMF), and v) (No. $39+\mathrm{BM})$ with vi) (No. $39+\mathrm{BM}+\mathrm{DMF})$ CL curves, an interesting comment should be made. As a matter of fact, according to previous study [32], the emission of singlet oxygen requires a hole. Therefore, it is a photo-induced ROS as it requires an electron-hole pair to be formed as well. However, obtained results suggest that there is also presence of singlet oxygen ${ }^{1} \mathrm{O}_{2}$ even in the dark. Hence, further study must be made on the exact mechanisms of formation of singlet oxygen under dark conditions. Table 2 shows

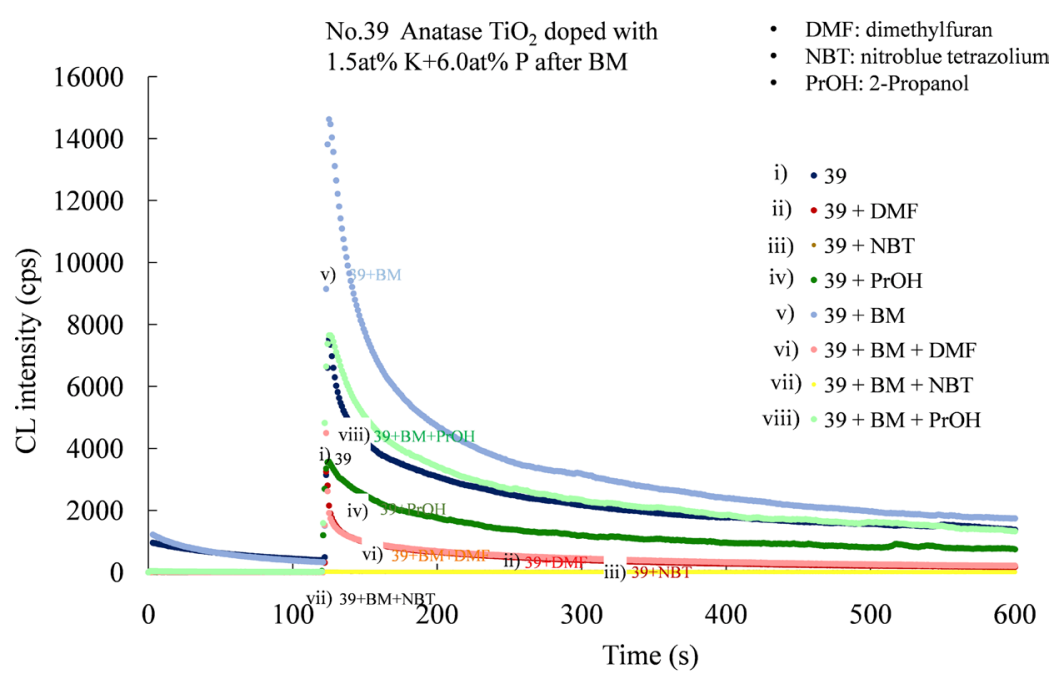

Figure 14. $\mathrm{CL}$ values of $1 \cdot \mathrm{K}+4 \cdot \mathrm{P}\left(\mathrm{K}=1.5\right.$ at\%) co-doped $a-\mathrm{TiO}_{2}($ No. 39$)$ with various scavengers. 
Table 2. ROS of $\mathrm{TiO}_{2}$ doped with various amounts of $\mathrm{K}$ and $\mathrm{P}$.

\begin{tabular}{|c|c|c|c|}
\hline Sample No. & $\mathrm{K}$ (at\%) & P (at\%) & ROS \\
\hline 18 & 0 & 5 & ${ }^{1} \mathrm{O}_{2}, \mathrm{O}_{2}^{-}, \cdot \mathrm{OH}$ \\
\hline 14 & 0 & 10 & ${ }^{1} \mathrm{O}_{2,} \cdot \mathrm{O}_{2}^{-}, \cdot \mathrm{OH}$ \\
\hline 35 & 0.75 & 2.25 & ${ }^{1} \mathrm{O}_{2,} \cdot \mathrm{O}_{2}^{-}$ \\
\hline 37 & 1.5 & 3 & ${ }^{1} \mathrm{O}_{2}, \mathrm{O}_{2}^{-}, \cdot \mathrm{OH}$ \\
\hline 38 & 1.5 & 4.5 & ${ }^{1} \mathrm{O}_{2}, \mathrm{O}_{2}^{-}$ \\
\hline 39 & 1.5 & 6 & ${ }^{1} \mathrm{O}_{2,} \cdot \mathrm{O}_{2}^{-}, \cdot \mathrm{OH}$ \\
\hline 41 & 3 & 9 & ${ }^{1} \mathrm{O}_{2,} \cdot \mathrm{O}_{2}^{-}$ \\
\hline
\end{tabular}

Both single doped and co-doped anatase powder heated in $\mathrm{O}_{2}$ submitted ROS under dark conditions.

the summary of what kinds of ROS were emitted from $\mathrm{K} / \mathrm{P}$ doped $a-\mathrm{TiO}_{2}$. It should be noted that hydroxyl radical $\mathrm{OH}$. which is much harmful to many kinds of bacteria was produced by $\mathrm{K} / \mathrm{P}$ doped $a-\mathrm{TiO}_{2}$ with the atomic ratios of $1 \cdot \mathrm{K}+n \cdot \mathrm{P}$, where $n$ was 2 and 4 . This means that a little deviated valance from +4 , i.e., $1 \cdot \mathrm{K}+2 \cdot \mathrm{P} \rightarrow 3.66(-0.34)$ and $1 \cdot \mathrm{K}+4 \cdot \mathrm{P} \rightarrow 4.2(+0.2)$ could be close relation to form $\cdot \mathrm{OH}$.

In order to evaluate the amount of ROS which were produced in various $\mathrm{pH}$ buffer solutions, ESR measurements [49] were performed without protection from light on the most efficient powder above mentioned, i.e., 1.5 at $\% \mathrm{~K}$ and 6 at $\% \mathrm{P}$ co-doped, calcined in $\mathrm{O}_{2}$ and ball milled powder (No.39+ BM). Applying a spin trapping method with a spin-trap agent of 2,2-oxo-5,5-dimethyl-1-pyrroline1yloxyl (DMPO), thus obtained ESR results are presented on Figure 15. In Figure 15(a), ESR spectra measured at various $\mathrm{pH}$ values from 7 to 10 are shown; it appears that from the detected signal which is originated from the DMPO-OH radical, the ROS emitted from $\mathrm{K} / \mathrm{P}$ doped $a-\mathrm{TiO}_{2}$ is mainly hydroxyl radical, indicating the opposite result shown in Figure 14. This could be explained that the difference in measuring conditions between CL and ESR; the former and the latter were performed under dark and light conditions, respectively.

In order to investigate the $\mathrm{pH}$ dependence of the ROS emission, an integral ESR signal was calculated. The result is shown in Figure 15(b). To this purpose, noise was eliminated and the integral was performed on the characteristic peaks of DMPO-OH radical only. From this figure, it was clear that ROS emission was the highest around $\mathrm{pH}=9.5$.

The ROS generation mechanism in doped anatase could be explained based on their non-stoichiometry as shown in Figure 16, metal-rich structure $\mathrm{Ti}_{1+x} \mathrm{O}_{2}(x>0)$ [29], $x$ in the formula represents the amount of interstitial titanium $\mathrm{Ti}_{\mathrm{i}}$ which is the main source to produce ROS [23] [24]. After doping of $\mathrm{K}$ or/and $\mathrm{P}$ and heating at high temperatures, $\mathrm{Ti}_{\mathrm{i}}$ will be created and increased. These $\mathrm{Ti}_{\mathrm{i}}$ will react with oxygen as following reaction: $\mathrm{Ti}_{\mathrm{i}}+2 \mathrm{O} \Leftrightarrow \mathrm{Ti}_{\mathrm{i}}^{4 \cdot}+4 \mathrm{e}^{-}+\mathrm{O}_{2}$. Then, ROS could be formed on the surface of $\mathrm{TiO}_{2}$ by the equations below. 


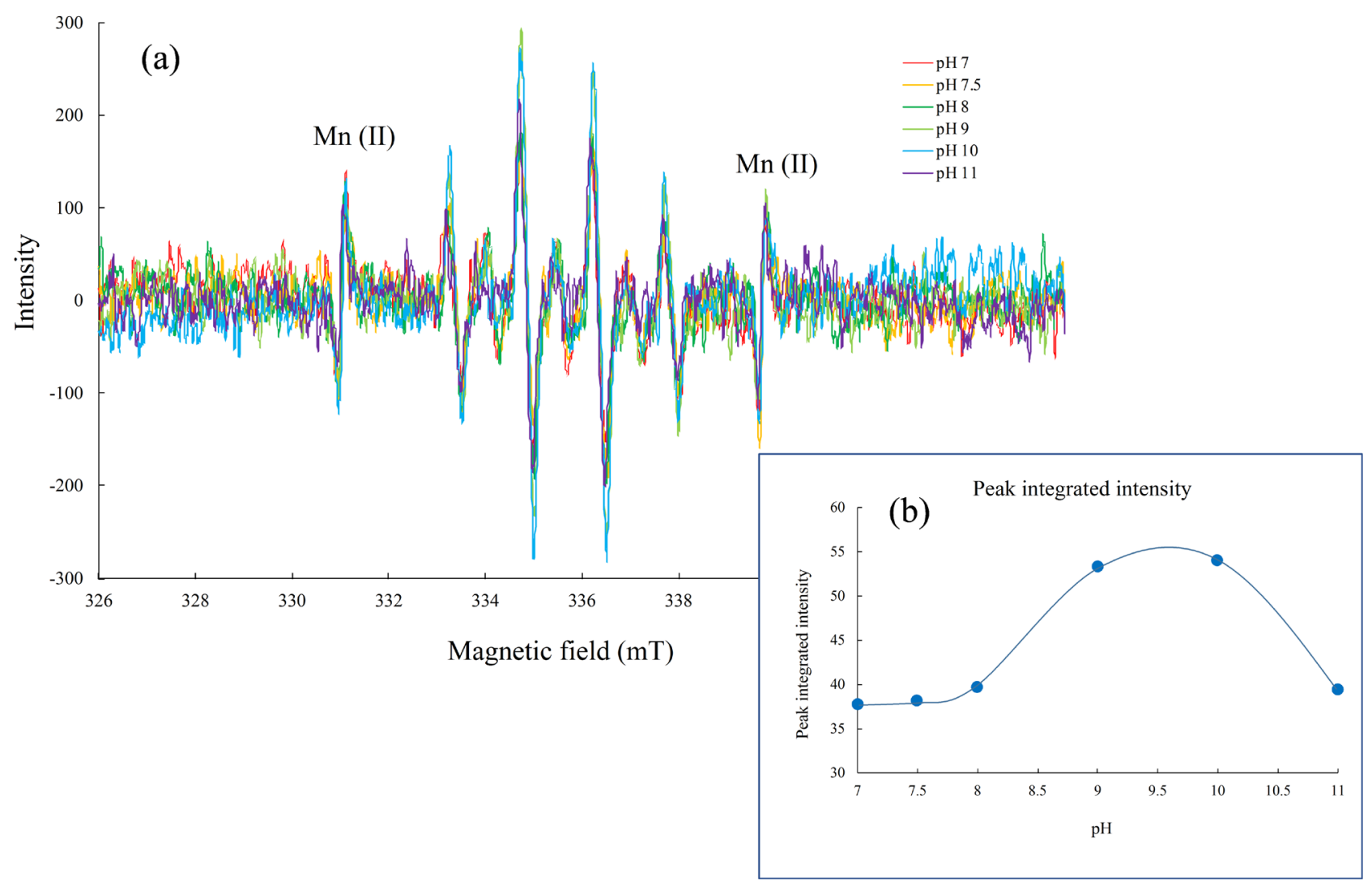

Figure 15. (a) ESR spectrum of co-doped $a-\mathrm{TiO}_{2}$ (No. 39) measured under various pH values. (b) Peak integral intensity of the ESR spectra at different $\mathrm{pH}$ values.

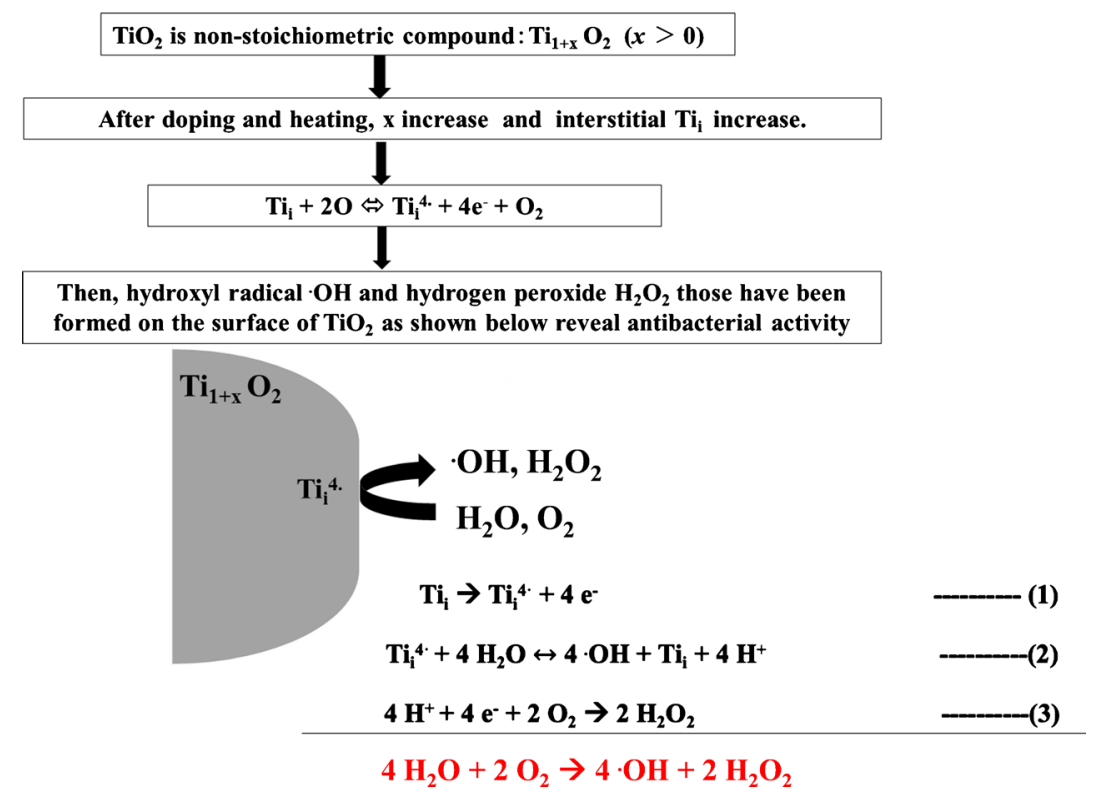

Figure 16. Proposed antibacterial mechanism for doped $a-\mathrm{TiO}_{2}$ under dark conditions.

$$
\begin{gathered}
\mathrm{Ti}_{\mathrm{i}} \rightarrow \mathrm{Ti}_{\mathrm{i}}^{4^{4}}+4 \mathrm{e}^{-} \\
\mathrm{Ti}_{\mathrm{i}}^{4^{4}}+4 \mathrm{H}_{2} \mathrm{O} \leftrightarrow 4 \cdot \mathrm{OH}+\mathrm{Ti}_{\mathrm{i}}+4 \mathrm{H}^{+}
\end{gathered}
$$




$$
4 \mathrm{H}^{+}+4 \mathrm{e}^{-}+2 \mathrm{O}_{2} \rightarrow 2 \mathrm{H}_{2} \mathrm{O}_{2}
$$

Eventually $4 \mathrm{H}_{2} \mathrm{O}+2 \mathrm{O}_{2} \rightarrow 4 \cdot \mathrm{OH}+2 \mathrm{H}_{2} \mathrm{O}_{2}$.

Thus, one of reactive oxygen species, hydroxyl radical $\cdot \mathrm{OH}$ could be produced from the surface of $a-\mathrm{TiO}_{2}$.

\section{Conclusion}

Anatase titanium dioxide $\left(a-\mathrm{TiO}_{2}\right)$ nanoparticle powders (NPS) have been prepared by combined doping of $\mathrm{K}$ and $\mathrm{P}$ with the atomic ratio of $\mathrm{K} / \mathrm{P}=1 / 3$ into high purity $(\geq 99.92 \%)$ a- $\mathrm{TiO}_{2}$ powder, followed by heating at $973 \mathrm{~K}$ for $3.6 \times 10^{3}$ $\mathrm{s}$ in oxygen atmosphere and ball-milled. These powders can submit much reactive oxygen species (ROS) under dark conditions. The microstructure and physicochemical properties such as lattice parameters, particle sizes $P_{s}$, and oxygen deficiency, reactive oxygen species (ROS) of thus prepared powders were examined using XRD, SEM, BET, XPS, FT-IR, XAFS, ESR and chemiluminescence (CL). The amount of ROS submitted from $a-\mathrm{TiO}_{2}$ NPS in the dark reached about 10 times higher than pure $a-\mathrm{TiO}_{2}$. Addition to this much hydroxyl radical $\mathrm{OH}$, one of ROS, has been recognized in $1 \cdot \mathrm{K}+2 \cdot \mathrm{P}$ or $1 \cdot \mathrm{K}+4 \cdot \mathrm{P}$ doped $a-\mathrm{TiO}_{2} \mathrm{NPS}$ in light interception. The mechanism of generation of ROS from the doped anatase powder has been also proposed. The present results will open new academic and industrial fields in which metal oxides can sterilize both bacteria and virus even under dark condition for better civil life in a future.

\section{Acknowledgements}

The authors express their appreciation to Dr. H. OJI (NUSR/AichiSR, Japan), for his technical assistance and advice for the EXAFS measurement of doped $a-\mathrm{TiO}_{2}$. The authors thank Ms. M. Toda of the Doshisha University Research Centre for Interfacial Phenomena, for FE-SEM and TEM observations of the samples.

\section{Conflicts of Interest}

The authors declare no conflicts of interest regarding the publication of this paper.

\section{References}

[1] Fischer, K., Gawel, A., Rosen, D., Krause, M., Latif, A.A., Griebe, J., et al. (2017) Low-Temperature Synthesis of Anatase/Rutile/Brookite $\mathrm{TiO}_{2}$ Nanoparticles on a Polymer Membrane for Photocatalysis. Catalyst, 7, 209-222. https://doi.org/10.3390/catal7070209

[2] Catauro, M., Tranquillo, E., Poggetto, G.D., Pasquali, M., Dell'Era, A. and Ciprioti, S.V. (2018) Influence of the Heat Treatment on the Particles Size and on the Crystalline Phase of $\mathrm{TiO}_{2}$ Synthesized by the Sol-Gel Method. Materials, 11, 2364-2374. https://doi.org/10.3390/ma11122364

[3] Pena, M., Meng, X., Korfiatis, G.P. and Jing, C. (2006) Adsorption Mechanism of Arsenic on Nanocrystalline Titanium Dioxide. Environmental Science \& Technology, 40, 1257-1262. https://doi.org/10.1021/es052040e 
[4] Kuo, C.Y., Wu, C.H., Wu, J.T. and Chen, Y.R. (2015) Synthesis and Characterization of a Phosphorus-Doped $\mathrm{TiO}_{2}$ Immobilized Bed for the Photodegradation of Bisphenol A under UV and Sunlight Irradiation. Reaction Kinetics, Mechanisms and Catalysis, 114, 753-766. https://doi.org/10.1007/s11144-014-0783-2

[5] Liou, J.W. and Chang, H.H. (2012) Bactericidal Effects and Mechanisms of Visible Light-Responsive Titanium Dioxide Photocatalysts on Pathogenic Bacteria. Archivum Immunologiae et Therapiae Experimentalis, 60, 267-275. https://doi.org/10.1007/s00005-012-0178-x

[6] Akpan, U.G. and Hameed, B.H. (2009) Parameters Affecting the Photocatalytic Degradation of Dyes Using $\mathrm{TiO}_{2}$-Based Photocatalysts: A Review. Journal of Hazardous Materials, 17, 520-529. https://doi.org/10.1016/j.jhazmat.2009.05.039

[7] Tachikawa, T., Tojo, S., Fujitsuka, M. and Majima, T. (2004) Influences of Adsorption on $\mathrm{TiO}_{2}$ Photocatalytic One-Electron Oxidation of Aromatic Sulfides Studied by Time-Resolved Diffuse Reflectance Spectroscopy. The Journal of Physical Chemistry $B, 108,5859-5866$. https://doi.org/10.1021/jp037003t

[8] Carp, O., Huisma, C.L. and Reller, A. (2004) Photoinduced Reactivity of Titanium Dioxide. Progress in Solid State Chemistry, 32, 133-177. https://doi.org/10.1016/j.progsolidstchem.2004.08.001

[9] Sunada, K., Watanabe, T. and Hashimoto, K. (2003) Studies on Photokilling of Bacteria on $\mathrm{TiO}_{2}$ Thin Film. Journal of Photochemistry and Photobiology A: Chemistry, 156, 227-233. https://doi.org/10.1016/S1010-6030(02)00434-3

[10] Akhavan, O. (2009) Lasting Antibacterial Activities of $\mathrm{Ag}-\mathrm{TiO}_{2} / \mathrm{Ag} / \mathrm{a}-\mathrm{TiO}_{2} \mathrm{Nano}-$ composite Thin Film Photocatalysts under Solar Light Irradiation. Journal of Colloid and Interface Science, 336, 117-124. https://doi.org/10.1016/j.jcis.2009.03.018

[11] Ashkarran, A.A., Aghigh, S.M., Kavianipour, M. and Farahani, N.J. (2011) Visible Light Photo- and Bioactivity of $\mathrm{Ag} / \mathrm{TiO}_{2}$ Nanocomposite with Various Silver Contents. Current Applied Physics, 11, 1048-1055. https://doi.org/10.1016/j.cap.2011.01.042

[12] Sun, C., Li, Q., Gao, S., Cao, L. and Shang, J.K. (2010) Enhanced Photocatalytic Disinfection of Escherichia coli Bacteria by Silver and Nickel Comodification of a Nitrogen-Doped Titanium Oxide Nanoparticle Photocatalyst under Visible-Light Illumination. Journal of the American Ceramic Society, 93, 531-535. https://doi.org/10.1111/j.1551-2916.2009.03388.x

[13] Yu, J.C., Ho, W.K., Lin, J., Yip, H. and Wong, P.K. (2003) Photocatalytic Activity, Antibacterial Effect, and Photoinduced Hydrophilicity of $\mathrm{TiO}_{2}$ Films Coated on a Stainless Steel Substrate. Environmental Science \& Technology, 37, 2296-2301. https://doi.org/10.1021/es0259483

[14] Sunada, K., Kikuchi, Y., Hashimoto, K. and Fujishima, A. (1998) Bactericidal and Detoxification Effects of $\mathrm{TiO}_{2}$ Thin Film Photocatalysts. Environmental Science \& Technology, 32, 726-728. https://doi.org/10.1021/es970860o

[15] Salih, F.M. (2002) Enhancement of Solar Inactivation of Escherichia coli by Titanium Dioxide Photocatalytic Oxidation. Journal of Applied Microbiology, 92, 920926. https://doi.org/10.1046/j.1365-2672.2002.01601.x

[16] Zaleska, A. (2008) Doped-TiO ${ }_{2}$ : A Review. Recent Patents on Engineering, 2, $157-$ 164. https://doi.org/10.2174/187221208786306289

[17] Le, P.H., Le, T.H., Lam, T.N., Nguyen, T.N.H., Nguyen, V.T., Le, T.C.T., et al. (2018) Enhanced Photocatalytic Performance of Nitrogen-Doped $\mathrm{TiO}_{2}$ Nanotube Arrays Using a Simple Annealing Process. Micromachines, 9, 618-630. https://doi.org/10.3390/mi9120618 
[18] Hou, J., Wang, L., Wang, C., Zhang, S., Liu, H., Li, S., et al. (2019) Toxicity and Mechanisms of Action of Titanium Dioxide Nanoparticles in Living Organisms. Journal of Environmental Science, 75, 40-53. https://doi.org/10.1016/j.jes.2018.06.010

[19] Venkatasubbu, D., Baskarb, R., Anusuya, T., Seshan, C.A. and Chelliah, R. (2016) Toxicity Mechanism of Titanium Dioxide and Zinc Oxide Nanoparticles against Food Pathogens. Colloids and Surfaces B: Biointerfaces, 148, 600-606. https://doi.org/10.1016/j.colsurfb.2016.09.042

[20] Iavicoli, I., Leso, V., Fontana, L. and Berganaschi, A. (2011) Toxicological Effects of Titanium Dioxide Nanoparticles: A Review of in Vitro Mammalian Studies. European Review for Medical and Pharmacological Sciences, 15, 481-508.

[21] Santhoshkumar, T., Rahuman, A.A., Jayaseelan, C., Rajakumar, G., Marimuthu, S., Kirthi, A.V., et al. (2014) Green Synthesis of Titanium Dioxide Nanoparticles Using Psidium guajava Extract and Its Antibacterial and Antioxidant Properties. Asian Pacific Journal of Tropical Medicine, 7, 968-976. https://doi.org/10.1016/S1995-7645(14)60171-1

[22] Hirota, K., Sugimoto, M., Kato, M., Tsukagoshi, K., Tanigawa, T. and Sugimoto, H. (2010) Preparation of Zinc Oxide Ceramics with a Sustainable Antibacterial Activity under Dark Conditions. Ceramics International, 36, 497-506. https://doi.org/10.1016/j.ceramint.2009.09.026

[23] Nguyen, T.M.P., Hirota, S., Suzuki, Y., Kato, M., Hirota, K., Taniguchi, H., et al. (2018) Preparation of ZnO Powders with Strong Antibacterial Activity under Dark Conditions. Journal of the Japan Society of Powder and Powder Metallurgy, 65, 316-324. https://doi.org/10.2497/jispm.65.316

[24] Nguyen, T.M.P., Hirota, K., Kato, M., Tsukagoshi, K., Yamada, H., Terabe, A., et al. (2019) Dependence of Antibacterial Activity of $\mathrm{ZnO}$ Powders on Their Physicochemical Properties. Journal of the Japan Society of Powder and Powder Metallurgy, 66, 435-441. https://doi.org/10.2497/jispm.66.434

[25] Chen, L.C., Huang, C.M. and Tsai, F.R. (2007) Characterization and Photocatalytic Activity of $\mathrm{K}^{+}$-Doped $\mathrm{TiO}_{2}$ Photocatalysts. Journal of Molecular Catalysis A: Chemical, 265, 133-140. https://doi.org/10.1016/j.molcata.2006.10.011

[26] Bessekhouad, Y., Robert, D., Weber, J.V. and Chaoui, N. (2004) Effect of AlkalineDoped $\mathrm{TiO}_{2}$ on Photocatalytic Efficiency. Journal of Photochemistry and Photobiology A: Chemistry, 167, 49-57. https://doi.org/10.1016/j.jphotochem.2003.12.001

[27] Yang, G., Yan, Z., Xiao, T. and Yang, B. (2013) Low-Temperature Synthesis of Alkalis Doped $\mathrm{TiO}_{2}$ Photocatalysts and Their Photocatalytic Performance for Degradation of Methyl Orange. Journal of Alloys and Compounds, 580, 15-22. https://doi.org/10.1016/j.jallcom.2013.05.074

[28] Yildizhan, M.M., Sturm, S. and Gulgun, M.A. (2016) Structural and Electronic Modifications on $\mathrm{TiO}_{2}$ Anatase by $\mathrm{Li}, \mathrm{K}$ or $\mathrm{Nb}$ Doping below and above the Solubility Limit. Journal of Materials Science, 51, 5912-5923. https://doi.org/10.1007/s10853-016-9893-8

[29] Hao, L., Guan, S., Takaya, S., Yoshida, H., Tochihara, M. and Lu, Y. (2017) Preparation of Visible-Light-Responsive $\mathrm{TiO}_{2}$ Coatings Using Molten $\mathrm{KNO}_{3}$ Treatment and Their Photocatalytic Activity. Applied Surface Science, 407, 276-281. https://doi.org/10.1016/j.apsusc.2017.02.097

[30] Yu, J.C., Zhang, L., Zheng, Z. and Zhao, J. (2003) Synthesis and Characterization of Phosphated Mesoporous Titanium Dioxide with High Photocatalytic Activity. Chemistry of Materials, 15, 2280-2286. https://doi.org/10.1021/cm0340781

[31] Lin, L., Lin, W., Zhu, Y., Zhao, B. and Xie, Y. (2005) Phosphor-Doped Titania-A 
Novel Photocatalyst Active in Visible Light. Chemistry Letters, 34, 284-285. https://doi.org/10.1246/cl.2005.284

[32] Shi, Q., Yang, D., Jiang, Z. and Li, J. (2006) Visible-Light Photocatalytic Regeneration of NADH Using P-Doped $\mathrm{TiO}_{2}$ Nanoparticles. Journal of Molecular Catalysis B: Enzymatic, 43, 44-48. https://doi.org/10.1016/j.molcatb.2006.06.005

[33] Pan, X., Yang, M.Q., Fu, X., Zhang, N. and Xu, Y.J. (2013) Defective $\mathrm{TiO}_{2}$ with Oxygen Vacancies: Synthesis, Properties and Photocatalytic Applications. Nanoscale, 5, 3601. https://doi.org/10.1039/c3nr00476g

[34] Lin, L., Lin, W., Xie, J., Zhu, Y., Zhao, B. and Xie, Y. (2007) Photocatalytic Properties of Phosphor-Doped Titania Nanoparticles. Applied Catalysis B: Environmental, 75, 52-58. https://doi.org/10.1016/j.apcatb.2007.03.016

[35] Jin, C., Zheng, R.Y., Guo, Y., Xie, J.L., Zhu, Y.X. and Xie, Y.C. (2009) Hydrothermal Synthesis and Characterization of Phosphorous-Doped $\mathrm{TiO}_{2}$ with High Photocatalytic Activity for Methylene Blue Degradation. Journal of Molecular Catalysis A: Chemical, 313, 44-48. https://doi.org/10.1016/j.molcata.2009.07.021

[36] Alfred, A.C., Olav, M.K. and Rance, A.V. (1995) Quantitative Analysis in Diffuse Reflectance Spectrometry: A Modified Kubelka-Munk Equation. Vibrational Spectroscopy, 9, 19-27. https://doi.org/10.1016/0924-2031(94)00065-O

[37] Mousset, E., Oturan, N. and Oturan, M.A. (2018) An Unprecedented Route of OH Radical Reactivity Evidenced by an Electrocatalytical Process: Ipso-Substitution with Perhalogenocarbon Compounds. Applied Catalysis B: Environmental, 226, 135-146. https://doi.org/10.1016/j.apcatb.2017.12.028

[38] Shannon, R.D. (1976) Revised Effective Ionic Radii and Systematic Studies of Interatomic Distances in Halides and Chalcogenides. Acta Crystallographica Section $A$, 32, 751-767. https://doi.org/10.1107/S0567739476001551

[39] Lin, X.C., Tijana, R., Zhiyu, W. and Marion, C.T. (1997) XAFS Studies of Surface Structures of $\mathrm{TiO}_{2}$ Nanoparticles and Photocatalytic Reduction of Metal Ions. The Journal of Physical Chemistry B, 101, 10688-10697. https://doi.org/10.1021/jp971930g

[40] Bandna, B., Santosh, K., Heung, N.L. and Rajesh, K. (2016) Formation of Oxygen Vacancies and $\mathrm{Ti}^{3+}$ State in $\mathrm{TiO}_{2}$ Thin Film and Enhanced Optical Properties by Air Plasma Treatment. Scientific Reports, 6, Article No. 32355. https://doi.org/10.1038/srep32355

[41] Ma, J., Li, W., Le, N.T., Díaz-Real, J.A., Body, M., Legein, C., et al. (2019) RedShifted Absorptions of Cation-Defective and Surface Functionalized Anatase with Enhanced Photoelectrochemical Properties. ACS Omega, 4, 10929-10938. https://doi.org/10.1021/acsomega.9b01219

[42] Fujishima, A. and Zhang, C.R. (2006) Titanium Dioxide Photocatalysis: Present Situation and Future Approaches. Chimie, 9, 750-760.

https://doi.org/10.1016/j.crci.2005.02.055

[43] Smith, B.A., Teel, A.L. and Watts, R.J. (2004) Identification of the Reactive Oxygen Species Responsible for Carbon Tetrachloride Degradation in Modified Fenton's Systems. Environmental Science \& Technology, 38, 5465-5469. https://doi.org/10.1021/es0352754

[44] Kozmér, Z., Takács, E., Wojnárovits, L., Alapi, T., Hernádi, K. and Dombi, A. (2016) The Influence of Radical Transfer and Scavenger Materials in Various Concentrations on the Gamma Radiolysis of Phenol. Radiation Physics and Chemistry, 124, 52 57. https://doi.org/10.1016/j.radphyschem.2015.12.011

[45] Kormali, P., Triantis, T., Dimotikali, D., Hiskia, A. and Papaconstantinou, E. (2006) 
On the Photooxidative Behavior of $\mathrm{TiO}_{2}$ and $\mathrm{PW}_{12} \mathrm{O}_{40}{ }^{3-}$ : $\mathrm{OH}$ Radicals versus Holes. Applied Catalysis B: Environmental, 68, 139-146. https://doi.org/10.1016/j.apcatb.2006.07.024

[46] Nishibori, S. and Namiki, K. (1998) Superoxide Anion Radical-Scavenging Ability of Fresh and Heated Vegetable Juices. Nippon Shokuhin Kagaku Kogaku Kaishi, 45, 144-148. https://doi.org/10.3136/nskkk.45.144

[47] Wang, L., Liu, S., Zheng, Z., Pi, Z., Song, F. and Liu, Z. (2015) Rapid Assay for Testing Superoxide Anion Radical Scavenging Activities to Natural Pigments by Ultra-High Performance Liquid Chromatography-Diode-Array Detection Method. Analytical Methods, 7, 1535-1542. https://doi.org/10.1039/C4AY02690J

[48] Ao, Y., Satoh, K., Shibano, K., Kawahito, Y. and Shioda, S. (2008) Singlet Oxygen Scavenging Activity and Cytotoxicity of Essential Oils from Rutaceae. Journal of Clinical Biochemistry and Nutrition, 43, 6-12. https://doi.org/10.3164/jcbn.2008037

[49] Noda, H., Oikawa, K., Ogata, T., Matsuki, K. and Kamada, H. (1986) Preparation Method and Characterization of Titanium Oxide (IV). Journal of the Chemical Society of Japan, 8, 1084-1090. (In Japanese) 